\title{
Recent advances in green solvents for lignocellulosic biomass pretreatment: Potential of choline chloride $(\mathrm{ChCl})$ based solvents
}

\author{
Chung Loong Yiin ${ }^{\text {a,*, Kok Liang Yap }}{ }^{a}$, Andrian Zi En Ku ${ }^{a}$, Bridgid Lai Fui Chin ${ }^{\mathrm{b}}$, \\ Serene Sow Mun Lock ${ }^{c}$, Kin Wai Cheah ${ }^{\mathrm{d}}$, Adrian Chun Minh Loy ${ }^{\mathrm{e}}$, Yi Herng Chan ${ }^{\mathrm{f}}$ \\ ${ }^{a}$ Department of Chemical Engineering and Energy Sustainability, Faculty of Engineering, Universiti Malaysia Sarawak (UNIMAS), Kota Samarahan 94300, Sarawak, \\ Malaysia \\ ${ }^{\mathrm{b}}$ Department of Chemical Engineering, Faculty of Engineering and Science, Sarawak Campus, Curtin University Malaysia, Miri 98009, Sarawak, Malaysia \\ ${ }^{\mathrm{c}} \mathrm{CO}_{2}$ Research Center (CO2RES), Department of Chemical Engineering, Universiti Teknologi PETRONAS, 32610 Seri Iskandar, Malaysia \\ ${ }^{\mathrm{d}}$ Energy and Environment Institute, University of Hull, Cottingham Road, Kingston upon Hull HU6 7RX, United Kingdom \\ ${ }^{\mathrm{e}}$ Chemical Engineering Department, Monash University, 3180, Victoria, Australia \\ ${ }^{\mathrm{f}}$ PETRONAS Research Sdn. Bhd. (PRSB), Lot 3288 \& 3289, Off Jalan Ayer Itam, Kawasan Institusi Bangi, 43000 Kajang, Selangor, Malaysia
}

\section{H I G H L I G H T S}

- Identified green solvents of current interest for biomass pretreatment.

- Discussed formation, types, materials and design methodologies of green solvents.

- Reviewed potential applications of choline chloride $(\mathrm{ChCl})$ based green solvents.

- Existing challenges of green solvents are emphasized for future research.

\section{A R T I C L E I N F O}

\section{Keywords:}

Lignocellulosic biomass

Pretreatment

Green solvents

Choline chloride

Biomass-to-energy

\section{G R A P H I C A L A B S T R A C T}

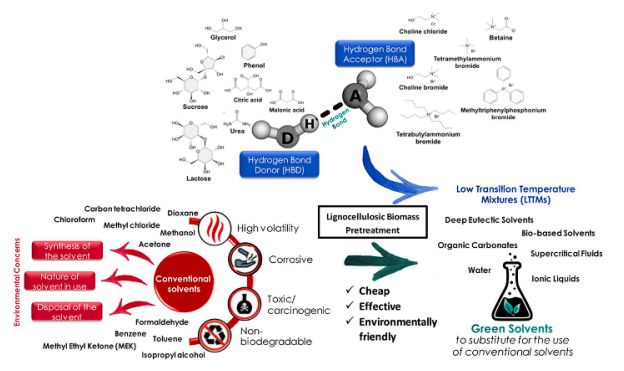

\begin{abstract}
A B S T R A C T
Biomass wastes exhibit a great potential to be used as a source of non-depleting renewable energy and synthesis of value-added products. The key to the valorization of excess lignocellulosic biomass wastes in the world lies on the pretreatment process to recalcitrant barrier of the lignocellulosic material for the access to useful substrates. A wide range of pretreatment techniques are available and advances in this field is continuously happening, in search for cheap, effective, and environmentally friendly methods. This review starts with an introduction to conventional approaches and green solvents for pretreatment of lignocellulosic biomass. Subsequently, the mechanism of actions along with the advantages and disadvantages of pretreatment techniques were reviewed. The roles of choline chloride $(\mathrm{ChCl})$ in green solvents and their potential applications were also comprehensively reviewed. The collection of ideas in this review serve as an insight for future works or interest on biomass-toenergy conversion using green solvents.
\end{abstract}

\footnotetext{
* Corresponding author.

E-mail addresses: clyiin@unimas.my (C.L. Yiin), kokliang1@live.com.my (K.L. Yap), andrianku@live.com (A.Z.E. Ku), bridgidchin@curtin.edu.my (B.L.F. Chin), sowmun.lock@utp.edu.my (S.S.M. Lock), K.Cheah@hull.ac.uk (K.W. Cheah), adrianminh@gmail.com (A.C.M. Loy), chan.yiherng@petronas.com.my (Y.H. Chan).
} 


\section{Introduction}

Biomass is often renowned as one of the cheapest and largest sources of non-depleting energy in the world, attributed with great potentiality for continuous and sustainable supply of energy in the form of biofuels and various value-added products in the near future (Zoghlami \& Paës, 2019; Kumar et al., 2020). Vast amount of lignocellulosic biomass is available for immediate global exploitation. Nonetheless, majority of the nations have yet to fully utilise and derive energy, chemicals and materials from the abundant biomass waste resources. For instance, in Malaysia, there are five major sectors that contribute to the generation of biomass wastes in the country, both directly and indirectly, namely forestry or so-called wood products, rubber cultivation, cocoa cultivation, sugar cane cultivation, and most importantly oil palm cultivation sector (Ratnasingam et al., 2015). Malaysia is currently ranked the world second largest palm oil producer which relatively accounts for the production of 7 million tonnes of crude palm oil. The country produces approximately 20 tonnes per hectare $\left(\mathrm{t} \mathrm{ha}^{-1}\right)$ of biomass residues from this sector every year (Yiin et al., 2019).

Lignocellulosic biomass is mainly composed of polysaccharides (cellulose and hemicelluloses) and an aromatic polymer (lignin), from which typical lignocellulosic biomass consists of $30-60 \%$ cellulose, 20-40\% hemicellulose and 15-25\% lignin (Dahadha et al., 2017). Nevertheless, the respective lignocellulosic contents in lignocellulosic biomass can be varied in accordance with the source and physical properties of the biomass, where some typical compositions of selected lignocellulosic biomass reported across several literatures are shown in Table 1. Valorizing, instead of disposing these biomass wastes is utterly important as these biomass wastes can serve as alternative feedstocks in place of the depleting fossil fuels, as well as to be transformed into various value-added products such as bio-derived fine chemicals and bio-fuels. Most importantly, they serve as inexpensive energy sources for

Table 1

Composition of selected lignocellulosic biomass wastes.

\begin{tabular}{|c|c|c|c|c|}
\hline $\begin{array}{l}\text { Lignocellulosic } \\
\text { Materials }\end{array}$ & $\begin{array}{l}\text { Cellulose } \\
(\%)\end{array}$ & $\begin{array}{l}\text { Hemicellulose } \\
(\%)\end{array}$ & $\begin{array}{l}\text { Lignin } \\
(\%)\end{array}$ & References \\
\hline Bamboo & 45.0 & 24.0 & 20.0 & (Li et al., 2015) \\
\hline $\begin{array}{l}\text { Coffee } \\
\text { Parchment }\end{array}$ & 22.0 & 18.0 & 53.0 & (Reis et al., 2020) \\
\hline Coffee Pulp & 33.0 & 29.0 & 26.0 & $\begin{array}{l}\text { (Peña-Lucio } \\
\text { et al., 2020) }\end{array}$ \\
\hline Corn Cob & 45.0 & 33.0 & 14.0 & $\begin{array}{l}\text { (Louis \& } \\
\text { Venkatachalam, } \\
\text { 2020) }\end{array}$ \\
\hline Corn Straw & 45.4 & 22.7 & 10.8 & (Fu et al., 2015) \\
\hline Corn Stover & 34.0 & 23.0 & 21.0 & (An et al., 2020) \\
\hline Elephant Grass & 36.0 & 24.0 & 28.0 & $\begin{array}{l}\text { (Scholl et al., } \\
\text { 2015) }\end{array}$ \\
\hline MD2 Pineapple & $30.0-42.0$ & $32.0-37.0$ & $32.0-37.0$ & $\begin{array}{l}\text { (Mansor et al., } \\
\text { 2019) }\end{array}$ \\
\hline Napier Grass & 47.0 & 31.0 & 22.0 & $\begin{array}{l}\text { (Reddy et al., } \\
\text { 2018) }\end{array}$ \\
\hline Newspaper & 55.0 & 40.0 & 30.0 & $\begin{array}{l}\text { (Anwar et al., } \\
\text { 2014) }\end{array}$ \\
\hline Oat hulls & $35.0-45.0$ & $32.0-35.0$ & $17.0-20.0$ & $\begin{array}{l}\text { (Santos et al., } \\
\text { 2020) }\end{array}$ \\
\hline $\begin{array}{l}\text { Oil Palm Empty } \\
\text { Fruit Bunch }\end{array}$ & 65.0 & 33.5 & 30.5 & (Yiin et al., 2019) \\
\hline Poplar & 49.9 & 28.7 & 19.2 & $\begin{array}{l}\text { (Zabed et al., } \\
\text { 2016) }\end{array}$ \\
\hline Rice Husk & 37.1 & 29.4 & 24.1 & $\begin{array}{l}\text { (Kalita et al., } \\
\text { 2015) }\end{array}$ \\
\hline Rice Straw & 42.0 & 25.0 & 24.0 & $\begin{array}{l}\text { (Zhang et al., } \\
\text { 2020) }\end{array}$ \\
\hline $\begin{array}{c}\text { Sugarcane } \\
\text { Bagasse }\end{array}$ & $40.0-50.0$ & $20.0-30.0$ & $20.0-25.0$ & $\begin{array}{l}\text { (Santos et al., } \\
\text { 2020) }\end{array}$ \\
\hline Wheat Straw & 35.0 & 22.3 & 15.6 & $\begin{array}{l}\text { (Bolado- } \\
\text { Rodríguez et al., } \\
\text { 2016) }\end{array}$ \\
\hline
\end{tabular}

the production of enzyme which are beneficial for microbial fermentation (Anwar et al., 2014; Yiin et al., 2018). As such, lignocellulosic biomass has indeed caught the interests of many researchers in recent times due to their nature of being renewable and cheap. However, the major limitation that impedes the valorisation of lignocellulosic biomass is mostly ascribed to the recalcitrance of plant cell walls to biochemical and biological decomposition, conferred by the heterogeneous polyphenolic structure of lignin (Zoghlami \& Paës, 2019). Therefore, the pretreatment of these lignocellulosic materials is introduced in order to unleash the trapped potential in lignocellulosic biomass and to promote the valorization of biomass waste.

The pretreatment of biomass has been extensively discussed in existing review papers such as in Baruah et al. (2018) and Zabed et al. (2016) which presented the conventional pretreatment approaches including physical, chemical, biological, and physicochemical pretreatment methods. Generally, it can be concluded that most of the conventional pretreatment techniques possess some of the disadvantages suchlike high energy requirement, high cost of equipment, lowscale applications, formation of inhibitors as well as nonenvironmentally friendly. Consequently, Baruah et al. (2018) highlighted the need for low cost, energy-effective, environmentally sustainable approach which are outseen as the bottlenecks for biomass valorization. Thus, this review provides a comprehensive review of pretreatment of lignocellulosic biomass by evaluating the conventional techniques, followed by the recent advances of green solvents in terms of current interest, chemistry behind, designing, challenges and future prospects as well as roles of $\mathrm{ChCl}$ in green solvents. Besides, the mechanism of actions, advantages and disadvantages associated with all the pretreatment approaches were also evaluated. This review article aims to come up with notable information for researchers who are dealing with the pretreatment of lignocellulosic biomass for waste-to-energy transformation.

\section{Conventional approaches for lignocellulosic biomass pretreatment}

The recalcitrance of plant cell walls to biochemical and biological decomposition, conferred by the heterogeneous polyphenolic structure of lignin, is deemed as the main concern when it comes to utilize the simple substrates trapped within the lignocellulosic biomass. In this sense, the pretreatment of lignocellulosic biomass plays a crucial role to ensure the recovery of cellulosic content from these lignin-based biomasses. As such, the lignin barrier in lignocellulosic biomass is disintegrated and broken down during the pretreatment process in order to recover the cellulose (Anwar et al., 2014). Additionally, the degree of polymerisation and crystallinity of cellulose are also altered, in which there is a reduction in both aspects (Chen et al., 2017). During the pretreatment process, the compact structure of lignocellulose is disrupted to overcome the recalcitrance through the combination of chemical and structural changes to the lignin and carbohydrates, exposing the cellulose fibers to allow enzymatic hydrolysis (Amin et al., 2017). All the advantages and disadvantages of various pretreatment methods are summarised in Table 2.

\subsection{Physical pretreatment}

It is essential for lignocellulosic biomass to undergo size reduction through mechanical processing. Physical pretreatment can be classified into several methods such as milling, microwave, extrusion and ultrasonication (Baruah et al., 2018). The main objective of physical pretreatment is to reduce and minimise the particle size. Correspondingly, this leads to the increase in the surface area, decrease in the degree of polymerisation as well as reduction in crystallinity (Rajendran et al., 2018). Apart from that, the processes also can be carried out smoothly and effectively. These pretreatment methods are deemed as environmental-friendly as they hardly produce toxic materials which 
Table 2

Comparative summary of different pretreatment methods.

\begin{tabular}{|c|c|c|c|c|}
\hline Pretreatment Methods & Solvents Used & Advantages & Disadvantages & Reference \\
\hline \multicolumn{5}{|l|}{ Physical pretreatment } \\
\hline Milling & - & $\begin{array}{l}\text { - High surface contact and pore } \\
\text { volume of biomass } \\
\text { - No formation of toxic and } \\
\text { inhibitory compounds }\end{array}$ & $\begin{array}{l}\text { - High energy demand } \\
\text { - High cost of mechanical } \\
\text { equipment }\end{array}$ & $\begin{array}{l}\text { (Bai et al., 2018; Baruah et al., } \\
\text { 2018) }\end{array}$ \\
\hline Microwave irradiation & Sodium chlorite; Hydrogen peroxide & $\begin{array}{l}\text { - Short process time } \\
\text { - Easy operation } \\
\text { - Highly selective } \\
\text { - Less inhibitors produced } \\
\text { - Faster heat transfer } \\
\text { - Eco-friendly }\end{array}$ & $\begin{array}{l}\text { - Poor distribution of microwave } \\
\text { power } \\
\text { - Uneven heating } \\
\text { - Low penetrating radiation }\end{array}$ & $\begin{array}{l}\text { (Baruah et al., 2018; Louis \& } \\
\text { Venkatachalam, 2020; Agu et al., } \\
\text { 2019) }\end{array}$ \\
\hline Extrusion & - & $\begin{array}{l}\text { - Short residence time } \\
\text { - Rapid mixing } \\
\text { - High shear } \\
\text { - Continuous operation } \\
\text { - Moderate barrel temperature } \\
\text { - Easy scale-up } \\
\text { - No formation of inhibitors } \\
\text { - Adaptable to process } \\
\text { modifications }\end{array}$ & $\begin{array}{l}\text { - High energy demand } \\
\text { - Partial hemicellulose } \\
\text { degradation } \\
\text { - Incomplete destruction of the } \\
\text { lignin-carbohydrate matrix in } \\
\text { certain materials }\end{array}$ & $\begin{array}{l}\text { (Capolupo \& Faraco, 2016; Mood } \\
\text { et al., 2013) }\end{array}$ \\
\hline Ultrasonication & - & $\begin{array}{l}\text { - High enzymatic digestibility } \\
\text { - Effective sugar production } \\
\text { - Reduction in the duration of } \\
\text { biomass hydrolysis } \\
\text { - Promotes the disruption of } \\
\text { lignocellulosic biomass }\end{array}$ & $\begin{array}{l}\text { - High energy demand } \\
\text { - Not suitable for high-scale } \\
\text { applications }\end{array}$ & (Luo et al., 2014) \\
\hline \multicolumn{5}{|l|}{ Chemical Pretreatment } \\
\hline $\begin{array}{l}\text { Concentrated acid } \\
\text { pretreatment }\end{array}$ & Sulphuric acid; p-Toluenesulfonic acid & $\begin{array}{l}\text { - Enhance the enzymatic } \\
\text { hydrolysis of cellulose and } \\
\text { hemicelluloses } \\
\text { - High sugar conversion rate } \\
\text { - Complete removal of } \\
\text { crystalline structure of } \\
\text { cellulose }\end{array}$ & $\begin{array}{l}\text { - Toxicity } \\
\text { - Equipment corrosion } \\
\text { - High cost of operation and } \\
\text { maintenance } \\
\text { - Acid recovery } \\
\text { - Formation of fermentation } \\
\text { inhibitors }\end{array}$ & $\begin{array}{l}\text { (An et al., 2020; Baruah et al., } \\
\text { 2018; Zabed et al., 2016) }\end{array}$ \\
\hline $\begin{array}{l}\text { Dilute acid } \\
\text { pretreatment }\end{array}$ & Dilute sulphuric acid & $\begin{array}{l}\text { - Economical } \\
\text { - Eco-friendly } \\
\text { - Improved digestibility } \\
\text { - Lesser inhibitors produced }\end{array}$ & $\begin{array}{l}\text { - Little lignin removal } \\
\text { - Requires neutralisation of the } \\
\text { pretreated slurry }\end{array}$ & (An et al., 2020; Zabed et al., 2016) \\
\hline Ozonolysis & Ethanol & $\begin{array}{l}\text { - Increased biodegradability of } \\
\text { cellulose fibrils } \\
\text { - Strong oxidant } \\
\text { - Low amounts of inhibitors } \\
\text { produced }\end{array}$ & $\begin{array}{l}\text { - Highly flammable, reactive, } \\
\text { corrosive } \\
\text { - High energy demand } \\
\text { - High generation costs }\end{array}$ & $\begin{array}{l}\text { (Mood et al., 2013; Zabed et al., } \\
\text { 2016) }\end{array}$ \\
\hline Alkaline pretreatment & $\begin{array}{l}\text { Sodium hydroxide; Potassium } \\
\text { hydroxide; Calcium hydroxide; } \\
\text { Ammonia }\end{array}$ & $\begin{array}{l}\text { - Reduction in crystallinity } \\
\text { - Decrease in degree of } \\
\text { polymerisation } \\
\text { - Increase of surface area and } \\
\text { porosity } \\
\text { - Low operating temperature } \\
\text { - Complex reactors are not } \\
\text { needed }\end{array}$ & $\begin{array}{l}\text { - Long residence time from hours } \\
\text { to days } \\
\text { - Neutralisation of the pretreated } \\
\text { slurry }\end{array}$ & $\begin{array}{l}\text { (Behera et al., 2014; Gao et al., } \\
\text { 2020; Mood et al., 2013) }\end{array}$ \\
\hline $\begin{array}{l}\text { Organosolv } \\
\text { pretreatment }\end{array}$ & $\begin{array}{l}\text { Ethanol; Methanol; Glycol; Glycerol; } \\
\text { Formic acid; Acetic acid; Acetone; } \\
\text { Phenol; Dioxane }\end{array}$ & $\begin{array}{l}\text { - Easy recovery } \\
\text { - Lignin obtained from the } \\
\text { pretreatment as value-added } \\
\text { by-products }\end{array}$ & $\begin{array}{l}\text { - Costly } \\
\text { - High energy demand } \\
\text { - Risky due to high pressure } \\
\text { - Highly flammable and volatile } \\
\text { - Formation of inhibitors }\end{array}$ & $\begin{array}{l}\text { (Borand \& Karaosmanoğlu, 2018; } \\
\text { Gao et al., 2020; Zhang et al., 2016) }\end{array}$ \\
\hline \multicolumn{5}{|l|}{ Biological Pretreatment } \\
\hline $\begin{array}{l}\text { Pretreatment with } \\
\text { micro-organisms }\end{array}$ & Potato dextrose agar & $\begin{array}{l}\text { - Low cost of operation } \\
\text { - Low energy demand } \\
\text { - No chemicals requirement } \\
\text { - Environmentally friendly and } \\
\text { sustainable }\end{array}$ & $\begin{array}{l}\text { - Long residence time } \\
\text { - Low efficiency } \\
\text { - Large space required } \\
\text { - Constant supervision of micro- } \\
\text { organisms growth }\end{array}$ & $\begin{array}{l}\text { (Bhatia et al., 2017; Maurya et al., } \\
\text { 2015; Peña-Lucio et al., 2020; } \\
\text { Sindhu et al., 2016) }\end{array}$ \\
\hline \multicolumn{5}{|c|}{ Physicochemical Pretreatment } \\
\hline Steam explosion & $\begin{array}{l}\text { Ethanol; Toluene; Sulphuric acid; } \\
\text { Potassium hydroxide; Sodium hydroxide }\end{array}$ & $\begin{array}{l}\text { - Low capital costs } \\
\text { - Minimum environmental } \\
\text { effect } \\
\text { - Limited use of chemicals } \\
\text { - Low energy demand } \\
\text { - High sugar recovery }\end{array}$ & $\begin{array}{l}\text { - Formation of inhibitors at harsh } \\
\text { conditions }\end{array}$ & $\begin{array}{l}\text { (Gao et al., 2020; Pielhop et al., } \\
\text { 2016; Reis et al., 2020; Verardi } \\
\text { et al., 2018) }\end{array}$ \\
\hline
\end{tabular}


Table 2 (continued)

\begin{tabular}{|c|c|c|c|c|}
\hline Pretreatment Methods & Solvents Used & Advantages & Disadvantages & Reference \\
\hline $\begin{array}{l}\text { Ammonia fiber } \\
\text { explosion (AFEX) }\end{array}$ & Liquid ammonia & $\begin{array}{l}\text { - Removal of hemicellulose } \\
\text { and lignin } \\
\text { - Reduction in cellulose } \\
\text { crystallinity } \\
\text { - No inhibitors formed }\end{array}$ & $\begin{array}{l}\text { - High operating cost } \\
\text { - Non-environmentally friendly } \\
\text { - Highly volatile } \\
\text { - Lignocellulosic biomass with } \\
\text { low lignin content is preferable } \\
\text { - High energy demand }\end{array}$ & $\begin{array}{l}\text { (Baruah et al., 2018; Gao et al., } \\
\text { 2020) }\end{array}$ \\
\hline $\begin{array}{l}\text { Supercritical } \mathrm{CO}_{2} \\
\text { explosion }\end{array}$ & Supercritical $\mathrm{CO}_{2}$ & $\begin{array}{l}\text { - Increased accessibility of } \\
\text { cellulose fibers to enzymatic } \\
\text { hydrolysis } \\
\text { - Non-flammability } \\
\text { - Non-toxicity } \\
\text { - Easy recovery }\end{array}$ & $\begin{array}{l}\text { - Unsuitable for lignocellulosic } \\
\text { biomass with no moisture content }\end{array}$ & $\begin{array}{l}\text { (Baruah et al., 2018; Bharathiraja } \\
\text { et al., 2018; Capolupo \& Faraco, } \\
\text { 2016) }\end{array}$ \\
\hline Liquid hot water (LHW) & Water & $\begin{array}{l}\text { - Removal of lignin } \\
\text { - Increased accessible surface } \\
\text { area } \\
\text { - No formation of toxic } \\
\text { materials } \\
\text { - Minimal inhibitors formed } \\
\text { - No catalysts or chemicals } \\
\text { requirement }\end{array}$ & $\begin{array}{l}\text { - High water demand } \\
\text { - High energy demand }\end{array}$ & $\begin{array}{l}\text { (Bhutto et al., 2017; Zhuang et al., } \\
\text { 2016) }\end{array}$ \\
\hline \multicolumn{5}{|l|}{ Green Solvents Pretreatment } \\
\hline $\begin{array}{l}\text { Deep eutectic solvents } \\
\text { (DESs) }\end{array}$ & $\begin{array}{l}\text { Choline chloride/Glycerol; } \\
\text { Choline chloride/Lactic acid }\end{array}$ & $\begin{array}{l}\text { - Disintegration of complex } \\
\text { structure } \\
\text { - Highly biodegradable and } \\
\text { sustainable } \\
\text { - Less costly } \\
\text { - Easily prepared } \\
\text { - Low energy demand }\end{array}$ & $\begin{array}{l}\text { - Hygroscopicity properties of } \\
\text { DESs } \\
\text { - Highly viscous }\end{array}$ & $\begin{array}{l}\text { (Chen et al., 2019; Zdanowicz et al., } \\
\text { 2018) }\end{array}$ \\
\hline Ionic liquids (ILs) & $\begin{array}{l}\text { Imidazolium-based }\left(\left[\left(\mathrm{C}_{3} \mathrm{~N}_{2}\right) \mathrm{X}_{\mathrm{n}}\right]^{+}\right) \\
\text {Ammonium-based }\left[\mathrm{NX}_{4}\right]^{+}\end{array}$ & $\begin{array}{l}\text { - Dissolution of hemicelluloses } \\
\text { and lignin } \\
\text { - Increased porosity and } \\
\text { amorphous structure of } \\
\text { cellulose } \\
\text { - Easily recovered and recycled } \\
\text { - High thermal stability } \\
\text { - Conducted at moderate } \\
\text { condition } \\
\text { - Non-volatile and non-toxic }\end{array}$ & $\begin{array}{l}\text { - Expensive } \\
\text { - Not suitable for large-scale } \\
\text { applications }\end{array}$ & $\begin{array}{l}\text { (Baruah et al., 2018; Chen et al., } \\
\text { 2017; Mood et al., 2013) }\end{array}$ \\
\hline $\begin{array}{l}\text { Low-transition- } \\
\text { temperature- } \\
\text { mixtures (LTTMs) }\end{array}$ & $\begin{array}{l}\text { L-lactic acid/Glycine; L-lactic acid/ } \\
\text { Choline chloride; L-lactic acid/L-alanine; } \\
\text { L-lactic acid/L-glutamic acid }\end{array}$ & $\begin{array}{l}\text { - Higher extraction yields } \\
\text { - Highly biodegradable and } \\
\text { sustainable } \\
\text { - Economical } \\
\text { - Non-toxic } \\
\text { - Non-flammable } \\
\text { - Easily prepared }\end{array}$ & $\begin{array}{l}\text { - Thermal stability is not based on } \\
\text { the thermal stability of starting } \\
\text { materials }\end{array}$ & $\begin{array}{l}\text { (Francisco et al., 2013; Kottaras } \\
\text { et al., 2017) }\end{array}$ \\
\hline
\end{tabular}

would pollute the environment (Shirkavand et al., 2016).

\subsubsection{Milling}

Milling is implemented in order to reduce the crystallinity and particle size of lignocellulosic biomass up to approximately $0.2 \mathrm{~mm}$. Nevertheless, biomass with particle size of less than $0.4 \mathrm{~mm}$ oftentimes has no notable effect on the rate and yield of hydrolysis (Baruah et al., 2018). Numerous milling methods have been introduced in which the types of milling method used will eventually determine the reduction in particle size and crystallinity. Moreover, the processing time and type of lignocellulosic biomass used would also has an impact on the particle size and crystallinity of the respective biomass. A research conducted by Bai et al. (2018) stated that the effective reduction in the particle size and decrease in crystallinity bring about high surface contact as well as pore volume of the biomass. In addition, the respective biomass has a low thermal degradation temperature.

\subsubsection{Microwave irradiation}

Microwave irradiation in general terms is an unconventional heating method for the lignocellulosic biomass pretreatment by the means of electromagnetic field. This method utilises dielectric polarisation to induce molecular collisions and further generates thermal energy which results in the disruption of the complex structure of lignocellulosic biomass (Aguilar-Reynosa et al., 2017). Microwave irradiation brings about disintegration of cellulose fibers through molecular collision with the use of dielectric polarisation. There are two types of microwave irradiation pretreatment namely atmospheric and high-pressure treatment. The microwave pretreatments under high pressure are usually carried out in a closed reactor at temperatures between $150^{\circ} \mathrm{C}$ and $250^{\circ} \mathrm{C}$ (Li et al., 2016). In recent years, most researchers have discovered that microwave pretreatment can actually be implemented along with other available pretreatment methods as an upgraded attempt.

\subsubsection{Extrusion}

Extrusion as the conventionally used physical pretreatment method often utilises a tight barrel which is equipped with temperature control in order to carry out the pretreatment of lignocellulosic biomass (Duque et al., 2017). In this method, the lignocellulosic materials are to be passed through the barrel at a temperature of greater than $300^{\circ} \mathrm{C}$. The recalcitrant structure of the lignocellulosic biomass is disintegrated attributable to the high operating temperature. Additionally, the rotating screw blades in the barrel produces shear forces which in return would also disrupt the structure (Kumar \& Sharma, 2017).

\subsubsection{Ultrasonication}

The pretreatment of lignocellulosic biomass via ultrasonication often 
utilises the ultrasonic radiation which is in accordance with the principle of cavitation (Ravindran \& Jaiswal, 2016). In this method, shear forces is generated from the cavitation which causes the complex network structure of lignocellulosic biomass to rupture. This will hence ease the extraction of desired cellulose, hemicellulose or lignin. There are numerous factors suchlike the ultrasound frequency, sonication power as well as the duration and temperature of sonication which tend to influence the efficiency of ultrasonication (Liyakathali et al., 2016).

\subsection{Chemical pretreatment}

Chemical pretreatment describes the involvement of organic or inorganic compounds that are known for their dissolvability of lignin, through interactions with the intrapolymer or interpolymer bonds of lignin, hemicellulose, and cellulose, leading to the disruption of the recalcitrant structure of the lignocellulosic materials (Jędrzejczyk et al., 2019). In general, the chemical pretreatment of lignocellulosic biomass can be classified into acid pretreatment, alkaline pretreatment, organosolv pretreatment, and ozonolysis.

\subsubsection{Acid pretreatment}

Fundamentally in the acid pretreatment, the presence of acid causes cellulose and hemicelluloses in the lignocellulosic biomass to be hydrolysed into monosaccharides. This is mainly due to the fact that the glucosidic bonds between these polysaccharides are susceptible to acid. The hydronium ions from acid catalyst disaggregates the long polysaccharide chains into sugar monomers. The enzymatic hydrolysis of cellulose and hemicelluloses can be carried out more easily after the acid pretreatment (Baruah et al., 2018). Acid pretreatment can be further categorised into concentrated acid pretreatment and dilute acid pretreatment. Conventionally, concentrated acid pretreatment is conducted at a percent acidity of $30-70 \%$ as well as at a temperature of lower than $100^{\circ} \mathrm{C}$. On the other hand, dilute acid pretreatment $(0.1-10 \%)$ is carried out at a higher temperature in the range of $100-250^{\circ} \mathrm{C}$. Nevertheless, both of the pretreatment methods have a similarity in which the pretreatment process depends on the characteristics of lignocellulosic biomass used (Baruah et al., 2018).

\subsubsection{Alkaline pretreatment}

Alkaline pretreatment in general utilises the working principle of solubilisation of lignin in alkali solution. Researches have stated that among all the alkaline reagents suchlike potassium hydroxide, calcium hydroxide and ammonium hydroxide used for the pretreatment process, it is found out that sodium hydroxide functions most effectively (Kim et al., 2016). In this pretreatment technique, the linkages between hemicelluloses and lignin are segmented and dissociated due to the saponification process (Sun et al., 2016). The solubilisation of lignin and hemicellulose further lead to the enhanced enzymatic hydrolysis of cellulose. Furthermore, the pretreatment with alkaline reagents also cause swelling in cellulose which indirectly changes the structure of lignocellulosic biomass. Subsequently, there will be a reduction in the crystallinity, decrease in the degree of polymerisation, increase of surface area as well as porosity of lignocellulosic biomass.

\subsubsection{Organosolv pretreatment}

Organosolv pretreatment in general terms is the utilisation of organic solvents to pre-treat various lignocellulosic biomass. Organic solvents such as methanol, ethanol, acetone, organic acid, organic peracid as well as ethylene glycol tend to break down the linkages between lignin and hemicellulose. The removal of lignin and solubilisation of hemicellulose cause an increase of surface area and pore volume of cellulose, thus making cellulose more accessible to enzymatic hydrolysis (Zhang et al., 2016). Commonly, the addition of mineral acids, bases and some other salts which act as catalysts will lower the pretreatment temperature and boost the delignification process (Borand \& Karaosmanoğlu, 2018).

\subsubsection{Ozonolysis}

In this process, ozone gas brings about the breakdown of both lignin and hemicelluloses which further results in the increase of accessibility of cellulose fibrils to enzymatic hydrolysis. The ozone gas used in this technique is known as a strong oxidant and soluble in water (Mood et al., 2013). Besides, the process is conducted at ambient condition and only forms a low amount of inhibitors.

\subsection{Biological pretreatment}

Biological pretreatment utilises microorganisms such as fungi to convert lignocellulosic biomass into more accessible compounds. This is related to the fact that some fungi are capable of producing enzymes which help in the degradation of lignin (Sindhu et al., 2016). There are different lignin-degrading enzymes available, however fungi are suitable for biological pretreatment as they have the potentiality to disintegrate lignocellulosic materials. Additionally, fungi play a crucial role in the removal of antimicrobial substances. White-rot, soft-rot, and brown fungi are known for lignin and hemicellulose removal with a very little effect on cellulose (Nauman Aftab et al., 2019). As compared to brown-rot and soft-rot fungi, white-rot fungi are widely used in the breakdown of lignin and hemicelluloses in biological pretreatment owing to its high sugar yield (Baruah et al., 2018). Hydrolytic system and ligninolytic system are among the two extracellular enzymatic systems involved in the pretreatment with microorganisms. However, the main difference between the two systems is that the disintegration of both cellulose and hemicelluloses occur in hydrolytic system. Meanwhile, ligninolytic system is accountable for the dissolution of lignin (Wagner et al., 2018). Generally, a reduction in the particle size and an increase in the moisture content would bring about high efficiency of biological pretreatment. The efficiency of biological pretreatment also increases with increasing pretreatment time and temperature.

\subsection{Physicochemical pretreatment}

Physicochemical pretreatment is a technique that operate in a hybrid approach, affecting both the physical parameters as well as their chemical bonding (bond cleavage) and intermolecular interactions (Zhao et al., 2012). Predominantly, physicochemical pretreatment can be classified into steam explosion, ammonia fiber explosion, carbon dioxide $\left(\mathrm{CO}_{2}\right)$ explosion as well as liquid hot water pretreatment.

\subsubsection{Steam explosion pretreatment}

The pretreatment of lignocellulosic biomass through steam explosion utilises both mechanical forces and chemical effects. Operating conditions such as high-pressure saturated steam in the range of 0.69-4.83 $\mathrm{MPa}$ as well as temperature of approximately $160-260^{\circ} \mathrm{C}$ are implemented in order to allow the water molecules penetrate through the substrate structure of the lignocellulosic biomass. The water molecules are forced to escape in an explosive way through a sudden reduction of pressure in the system (Baruah et al., 2018). This phenomenon results in major parts of the lignocellulosic biomass to be splitted into fibers. Furthermore, the glycosidic bonds in cellulose and hemicellulose as well as the segmentation of hemicellulose-lignin bonds are also broken down due to the relatively high operating pressure and temperature of steam explosion pretreatment (Chen \& Liu, 2015). Hemicelluloses are also hydrolysed into respective glucose and xylose monomers throughout this pretreatment method (Singh et al., 2015). The factors which affect the pretreatment process are steam temperature, residence time, the size and moisture content of lignocellulosic biomass.

\subsubsection{Ammonia fiber explosion (AFEX)}

In AFEX, liquid ammonia is used to heat the lignocellulosic biomass in a closed vessel at a ratio of 1:1. Commonly, AFEX is conducted under high pressure of 1.72-2.06 MPa along with a moderate temperature around $60-100^{\circ} \mathrm{C}$ (Brodeur et al., 2011). This pretreatment process is 
lasted for approximately 5 to $30 \mathrm{~min}$. Similar to the steam explosion technique as discussed previously, AFEX also undergoes a sudden reduction of pressure (Shirkavand et al., 2016). This results in the disruption of the fibrous structure of lignocellulosic biomass and reduction in cellulose crystallinity. Thus, the enzymatic hydrolysis of lignocellulosic biomass can be further enhanced. AFEX pretreatment is influenced by several factors such as the operating temperature, blowdown pressure, residence time, ammonia loading as well as water loading (El-Naggar et al., 2014).

\subsubsection{Supercritical $\mathrm{CO}_{2}$ explosion}

In supercritical $\mathrm{CO}_{2}$ explosion pretreatment, $\mathrm{CO}_{2}$ molecules are allowed to diffuse through the lignocellulosic biomass under a considerably high pressure which causes the disintegration of hemicellulose and lignin structure of lignocellulosic biomass. The carbonic acid which formed from the dissolved $\mathrm{CO}_{2}$ in water promotes the hydrolysis reaction of hemicellulose (Baruah et al., 2018). The cellulose crystalline structure of lignocellulosic biomass can also be broken down through the sudden release of pressurised gas which increased the accessibility of cellulose fibers to enzymatic hydrolysis (Capolupo \& Faraco, 2016). A higher rate of penetration of the $\mathrm{CO}_{2}$ molecules into the cellulosic pores can be achieved by increasing the operating pressure which brings about a high glucose conversion (Baruah et al., 2018).

\subsubsection{Liquid hot water (LHW)}

LHW pretreatment utilises water to conduct the pretreatment process with a high operating temperature in the range of $170-230^{\circ} \mathrm{C}$ and a pressure of within $5 \mathrm{MPa}$. The lignocellulosic biomass is set to expose to the hot water for roughly $15 \mathrm{~min}$ residence time. Hemicellulose is hydrolysed by LHW through the removal of lignin and the discharge of acetyl groups in hemicellulose which enhance the accessibility of cellulose fibers to enzymes (Zhuang et al., 2016). LHW pretreatment is conducted at the $\mathrm{pH}$ of 4 to 7 in order to prevent the degradation of sugar as well as the formation of inhibitors (Baruah et al., 2018).

\subsection{Green solvents pretreatment}

In recent years, green solvents have been introduced and implemented for the pretreatment of lignocellulosic biomass in replacement of other conventional pretreatment techniques mainly due to its environmentally friendly nature. Predominantly, there are various types of green solvents available for biomass pretreatment which include ionic liquids (ILs), deep eutectic solvents (DESs) and low-transitiontemperature-mixtures (LTTMs).

\subsubsection{Ionic liquids (ILs)}

ILs are classified as organic salts which are made up of both cations and anions with a melting point of lower than $100^{\circ} \mathrm{C}$ (Baaqel et al., 2020; Baruah et al., 2018). Besides, ILs show the potential to dissolve lignin and carbohydrates contemporaneously. The formation of strong hydrogen bonds between the ILs' non-hydrated ions and the hydroxyl protons of sugars contributes to the disruption of crystalline structure of cellulose as well as dissolution of hemicelluloses and lignin. Several factors such as the cations, anions, operating temperature and treatment time tend to show an impact on the overall pretreatment process (Yoo et al., 2017). Generally, lignocellulosic biomass that is pre-treated with ILs results in an increased porosity and amorphous structure of cellulose. Accordingly, its accessibility to enzymatic hydrolysis by cellulases can be increased (Li et al., 2016).

\subsubsection{Deep eutectic solvents (DESs)}

DESs are considered as a different class of green solvents which are comparable to ILs from the perspective of their physicochemical properties. DESs have been extensively acknowledged as analogues of ILs and developed as the new representative for green solvents (Hussin et al., 2020). The term DES was introduced back in 2003 by Abbott et al. which encompass a new class of designer solvent system that comprises of natural and renewable starting materials that are widely available and near inexhaustible in nature. DESs are often constituted of two components which are connected to each other by strong hydrogen bonds. The eutectic mixture formed has a melting point lower than each individual component. DESs are simply made up of one hydrogen bond donor (HBD) and one hydrogen bond acceptor (HBA). Besides, the respective solvents are usually liquids at temperature below $100^{\circ} \mathrm{C}$ (Baruah et al., 2018). The pretreatment of lignocellulosic biomass with DESs promotes the disruption and disintegration of the complex structure of lignocellulosic materials. Xu et al. (2016) reported that the acidic HBD of DES tends to improve the overall efficiency of delignification and the dissolution of hemicellulose.

\subsubsection{Low-transition-temperature-mixtures (LTTMs)}

The original term DESs does not provide a thorough description to delineate the new class of solvents due to the fact that many of these solvents actually demonstrate glass transitions instead of eutectic (melting) points. Hence, Francisco et al. (2013) coined the term LTTMs to describe the solvents that are synthesized by mixing two or more solid components capable of establishing hydrogen bond interactions which results in liquid solvents with much lower melting point than any of its respective constituents. However, most literatures used both terms, LTTMs and DESs, interchangeably.

LTTMs in general can be regarded as one of the newly designed green solvents which are effective for the pretreatment of lignocellulosic biomass through delignification process. LTTMs are quite comparable with DESs in which these types of solvents are also composed of one HBD and one HBA (Kottaras et al., 2017). In addition, the pretreatment with LTTMs is capable of achieving a higher extraction yields as compared to conventional solvents (Kottaras et al., 2017). For instance, a study conducted by Yiin et al. (2018) involving the pretreatment of lignocellulosic biomass with malic acid-based LTTMs demonstrated high delignification selectivity, and improved enzymatic hydrolysis, as well as thermal degradation of biomass.

\section{Recent advances in green solvents}

Traditionally, the pretreatment of lignocellulosic biomass rely heavily on conventional solvents and the intensive use of conventional solvents worldwide is often regarded as a threat to the environment, where the concerns arise in three main areas: the synthesis of the solvent, the nature of the solvent in use, and the disposal (Welton, 2015). Most conventional solvents are considered damaging due to the large quantities in use and these solvents are often associated with their properties of being highly volatile, corrosive, toxic or carcinogenic, nonbiodegradable, etc. (Mallakpour \& Dinari, 2012). In this context, growing research on green solvents actively seeks to explore environmentally friendly and tunable solvents that meet both the economic demand and technological demand, specifically on the performance of the green solvents that are intended to replace existing solvents.

\subsection{Green solvents of current interest}

Green solvents encompass those which are non-toxic, non-volatile, recyclable, biodegradable, low-cost and preferably made from materials that are readily available (Das et al., 2017). Solvents of current interest that are recognized as green solvents include water, supercritical fluids, organic carbonates, ILs, DESs, and bio-based solvents (Welton, 2015). Among these classes of green solvents, ILs emerged as a competitive candidate which finds a versatile application in various fields such as bio-catalysis, separation process, electrochemical and biopolymers processing. ILs are molten salts in form of liquid at room temperature and exhibits interesting characteristics, which includes their physicochemical properties (melting point, density, surface tension, refractive index, viscosity, electrical conductivity, polarity, water and cosolvent 
miscibility, etc.) that can be tailored to needs by the combination of different cations and anions (Mallakpour \& Dinari, 2012; Paiva et al., 2014). The ILs which are of high thermal stability and low vapor pressure also offer advantages such as easy containment or storage, final product recovery, and recyclability of the solvent (Mallakpour \& Dinari, 2012).

Despite the promising characteristics of ILs as solvent, the widespread use of ILs in the industry is impeded by economic and environmental imperatives that are commonly associated with their controversial ecotoxicological data, flammability, high cost, complex synthesis method and purification process, etc. (Durand et al., 2015; Taylor et al., 2019). The "greenness" of ILs are often questioned due to their limitations in terms of poor biodegradability, biocompatibility, and solvent recoverability as well as their economic viability since the cost of ILs are relatively expensive compared to conventional solvents (Francisco et al., 2012). Furthermore, ILs are commonly derived from materials that use fossil resources, whereby the complex synthesis process involves the use of different reagents, other volatile organic compounds and create a large amount of chemical waste (Ratti, 2014).

On another note, it is worth mentioning that an alternative approach that is capable of overcoming the aforementioned drawbacks is the development of choline-based ILs wholly originated from biomaterials which have attractive features of low toxicity, relatively high stability and fewer negative effects on the environment, pioneered by Fukaya et al. (2007) and known as "Bio-ILs". The idea was adopted to create novel acetylcholine-carboxylate bio-ionic liquids for catalytic fixation of $\mathrm{CO}_{2}$ to produce fine chemicals (Zhao et al., 2019). In another instance, choline-based bio-ILs were applied in nanomaterials and polymers field (Noshadi et al., 2017). However, further studies are limited and could be of another interesting topic awaiting exploration.

DESs/LTTMs that can be easily synthesized from natural and readily acquirable raw materials, came up as an inexpensive and promising alternative to conventional ILs. The wide liquid range and befitting physicochemical properties evinced the key qualities of DESs/LTTMs suitable to be used as solvents. The strong hydrogen bond interactions are accredited for the similar benefits exhibited by DESs/LTTMs as compared to ILs while at the same time overcome the limitations of conventional ILs. Although both DESs/LTTMs and ILs present highly similar core characteristics, DESs/LTTMs are deemed a more complete representation of the green chemistry benchmarks, rendering LTTMs a compelling interest as the more favourable alternative compared to their analogue ILs (Silva et al., 2019).

\subsection{Chemistry behind DESs/LTTMs}

\subsubsection{Overview on formation of DESs}

DESs are system of eutectic mixtures formed between a HBA, most dominantly quaternary ammonium salts; and a HBD from a wide range of components such as alcohols, acids, amines, carbohydrates, among others. DESs are generally described by the following formula (Smith et al., 2014).

$\mathrm{Cat}^{+} \mathrm{X}^{-} \approx \mathrm{Y}$

where

$\mathrm{Cat}^{+}$refers to any ammonium $\left(\mathrm{NR}_{4}^{+}\right)$, phosphonium $\left(\mathrm{PR}_{4}^{+}\right)$, or sulphonium cation $\left(\mathrm{SR}_{3}^{+}\right)$

$\mathrm{X}$ is a Lewis base, generally a halide anion $\left(\mathrm{F}^{-}, \mathrm{Cl}^{-}, \mathrm{Br}^{-}, \mathrm{I}^{-}\right.$, etc.)

$\mathrm{Y}$ is either a Lewis or Brønsted acid

s refers to the number of molecules $\mathrm{Y}$ that interact with the anion

The complex anionic species forms between the halide anion $\mathrm{X}^{-}$with another Lewis or Brønsted acid Y, resulting in the charge delocalization between anion and the HBD compounds. The hydrogen-bonding interactions between a compatible pair of HBA and HBD is suggested to be responsible for the formation of the eutectic mixture (Francisco et al., 2013).
DESs/LTTMs constitute of a group of easily tunable eutectic mixtures that are adjustable to suit for specific applications, ascribed to their high number of HBDs present in the mixture (Bernasconi et al., 2017). Although the formation and functioning of these green solvents are not fully understood at their molecular level, the hydrogen bonds between the two hydrogen bonding constituents (HBA and HBD) are known to be responsible for the formation of DESs/LTTMs. The existence of hydrogen bond formation between the HBA and HBD in DESs/LTTMs can be verified through proton nuclear magnetic resonance $\left({ }^{1} \mathrm{H}\right.$ NMR) spectroscopy or Fourier-transform infrared spectroscopy (FTIR) (Haraźna et al., 2019). In this context, analyzing the changes in FTIR spectra of the synthesized DESs /LTTMs in comparison with the individual starting materials able to identify the chemical bonds and functional groups based on the assigned characteristic range of wavenumbers. Similarly, the trend of chemical shift in terms of ${ }^{1} \mathrm{H}$ NMR interpretation of the DESs/LTTMs in comparison with the individual constituents can be taken as the indicator for the formation of hydrogen bonds and changes in hydrogen bond strength. The extensive hydrogen bonding interaction renders the depression in the melting/freezing point of LTTMs.

\subsubsection{Types of DESs}

Depending on the nature of its constituents, there are four dominant types of DESs with the addition of type V DESs as a new idea that was proposed recently as shown in Table 3. Type I eutectics comprise of quaternary ammonium salts and non-hydrated metal halides, including a wide range of eutectic mixtures from chloroaluminate or imidazolium to less common 1-ethyl-3-methylimidazolium chloride (EMIC), with different metal halides well studied in the 1980s (Bernasconi et al., 2017). The range of suitable non-hydrated metal halides with low melting point to form type I DESs is limited, giving rise to type II eutectics, where many metal salts hydrates were coupled with quaternary ammonium salts following their inertness to air or moisture.

Most DESs are built on the fundamental of type III eutectics, where the most typical starting materials involve quaternary ammonium salts such as $\mathrm{ChCl}$ and $\mathrm{HBDs}$ such as glycol, ethylene glycol, urea, carboxylic acids, amides, and etc. (Zhekenov et al., 2017). Type III eutectics have been of great interest due to their solvation ability across a wide range of transition metal species, including chlorides, and oxides derivatives (Smith et al., 2014). These eutectic mixtures demonstrated high inertness with water to the extent of being almost unreactive, making them relatively easy to prepare and handle.

While most ILs and DESs involve a quaternary ammonium salt as the cationic component, giving a sense of quaternary ammonium salts being a requirement to form eutectics. However, it has been confirmed that the mixture of metal chloride hydrate and HBDs such as simple amides $\left(-\mathrm{CONH}_{2}\right)$ or alcohols $(-\mathrm{OH})$ forms a metalliferous solution composed of cations and anions via disproportionation processes (Abood et al., 2011). These DESs composed of metal chloride salts and HBDs without organic quaternary ammonium cations are the most recent class of DESs well established so far, known as type IV eutectics.

Type V DESs composed of non-ionic species are the most recent

Table 3

Classification of eutectics based on the nature of the complexing agent and their respective general formulas (Abranches et al., 2019; Kalhor \& Ghandi, 2019; Smith et al., 2014).

\begin{tabular}{lll}
\hline Type & General Formula & Terms \\
\hline I & $\mathrm{Cat}^{+} \mathrm{X}^{-} \approx \mathrm{MCl}_{\mathrm{x}}$ & $\mathrm{M}=\mathrm{Zn}, \mathrm{Sn}, \mathrm{Fe}, \mathrm{Al}, \mathrm{Ga}, \mathrm{In}$ \\
II & $\mathrm{Cat}^{+} \mathrm{X}^{-} \approx \mathrm{MCl}_{\mathrm{x}} \cdot \mathrm{yH} 2 \mathrm{O}$ & $\mathrm{M}=\mathrm{Cr}, \mathrm{Co}, \mathrm{Cu}, \mathrm{Ni}, \mathrm{Fe}$ \\
III & $\mathrm{Cat}^{+} \mathrm{X}^{-} \approx \mathrm{RZ}$ & $\mathrm{Z}=\mathrm{CONH}, \mathrm{COOH}, \mathrm{OH}$ \\
IV & $\mathrm{MCl}_{\mathrm{x}}+\mathrm{RZ}=\mathrm{MCl}_{\mathrm{x}-1}^{+} \cdot \mathrm{RZ}+\mathrm{MCl}_{\mathrm{x}+1}^{-}$ & $\mathrm{M}=\mathrm{Al}, \mathrm{Zn} ;$ and $\mathrm{Z}=\mathrm{CONH}_{2}, \mathrm{OH}$ \\
V & "Non-ionic DESs & $\begin{array}{l}\text { Composed only of molecular } \\
\text { substances }\end{array}$ \\
\hline
\end{tabular}

\footnotetext{
" Type V DES: Recently proposed and not well established (Abranches et al.,
} 2019). 
breakthrough. These non-ionic hydrophobic eutectics offset the limitations associated with hydrophobic eutectics based on quaternary ammonium salts, specifically their higher cost, hydrophobicity, viscosity, and also shown potential for the recovery and regeneration of the DES by evaporation, attributed to their non-ionic nature (Abranches et al., 2019). However, type V DESs is an area of research that is relatively new, hence still immature to support different scientific research.

\subsection{Designing green solvents}

\subsubsection{Starting materials of DESs/LTTMs}

The vast library of feasible constituents for the starting materials grants ubiquity to DESs/LTTMs ascribed to the ability in controlling and fine-tuning the physicochemical properties and phase behavior simply by altering the composition of the DESs/LTTMs. Apart from that, the solvation ability of DESs/LTTMs on solutes with different natures can also be tweaked for task-specific applications. DESs/LTTMs can easily be synthesized from readily available natural sources, simply by mixing two solid starting materials at moderate temperature without the need for further purification steps to form liquid eutectics by hydrogen bond interactions.

Theoretically, there is a near infinite number of combinations that could be rendered out of the numerous HBA and HBD constituents available. However, the compatibility of the mixture prepared by simple mix-and-match approach is not always guaranteed. In this sense, successful formation of DESs/LTTMs are characterized by solution that remains stable, homogenous, and colourless after cooled down to room temperature (Hussin et al., 2020).

\subsubsection{Design methodologies}

Despite the ease to synthesize DESs/LTTMs as compared to ILs, the designing of DESs/LTTMs are rather difficult. The potential constituents of ILs are limited to bulky or asymmetric ions, by which the fixed molar ratio of the ions in ILs is defined by the electroneutrality of the solution (Mainberger et al., 2017). In contrast, the complexity in designing DESs/ LTTMs is ascribed to the wide array of possibilities in formulating the molar ratio of the components in DESs/LTTMs that could be of any value (Alhadid et al., 2020). The time and cost for the synthesis and testing of such an impossibly large number of DESs/LTTMs poses a scientific challenge, given that the area of research is relatively new and lacks a comprehensive framework for the optimal design of DESs/LTTMs.

Most of the published works to date adopts the trial and error methodology in designing the DESs/LTTMs, where the preselected components are mixed at several molar ratios, typically $1: 1$ or $1: 2$, and mixtures that remain liquid at room temperature are documented for further studies (Alhadid et al., 2020). However, making selections based on the trial-and-error method can be very limiting and have a high chance to overlook good candidates (Rodriguez-Donis et al., 2018). It was emphasized that the trial-and-error method was too time consuming and costly (Azmin et al., 2015). To offset the limitations of the trial-anderror approach, Zhou et al. (2020) mentioned two categories of solvent selection and design methods, namely database screening, and molecular design.

Predictive design methodologies make use of the valuable experimental data from traditional trial-and-error approach for the screening of solvents. Rigorous modelling of predictive models can be implemented to compute the properties of the target molecules to reduce the exhausting and costly experimental efforts, and allowing more feasible designs to be explored. A pre-specified set of solvent candidates are screened based on the prediction of properties to identify the best solvent with matching specifications from a known set of candidates (Zhou et al., 2020).

The advancements in theoretical and modelling methods today, synchronous with robust computing power, enabled the possibility to incorporate computational methods in the selection and design of solvents (Kovács et al., 2020). Reverse design methodology is an innovative and systematic approach that combines the predictive capability of solvent properties with computer-aided molecular design (CAMD) tools to support the design of novel solvents that meet target specifications (Bergez-Lacoste et al., 2014).

The chronology of DESs/LTTMs development are similar to other solvents from the state of infancy to maturity, starting from the widely used trial-and-error approach to investigate the fundamental correlations, before predictive models can be developed for the prediction of molecular properties, then further advanced to involve the use of computational tools as seen in the reverse design methodology (BergezLacoste et al., 2014). Still in its infancy, DESs/LTTMs are not well characterized and understood to pursue for advanced design strategies due to the limitations in providing a comprehensive description of their physicochemical properties as the pre-requisite for advanced modelling and computational approaches.

\section{Roles of choline chloride $(\mathrm{ChCl})$ in green solvents}

The emergence of LTTMs can be traced back to the early years in the 21st century when Abbott et al. (2003) discovered that $\mathrm{ChCl}$ and urea forms a homogeneous solution at ambient temperature and pioneered the idea on DESs. Since then, $\mathrm{ChCl}$ appeared to be the most dominant quaternary ammonium salt to be used as the HBA in DESs/LTTMsrelated studies. The vast interest in $\mathrm{ChCl}$ sparked an exponential growth of the studies on ChCl-based DESs over the years. Apart from being popularized by the original author, the other contributing factors to the popularity of $\mathrm{ChCl}$ being used as the HBA in DESs/LTTMs are its relatively low cost, and other natures such as biodegradable, non-toxic, etc., that satisfies the green chemistry metrics.

\subsection{ChCl-based solvents for lignocellulosic biomass pretreatment}

ChCl-based green solvents find applications in a wide array of fields where lignocellulosic biomass pretreatment is regarded one of its most prospective use. Some of the $\mathrm{ChCl}$-based solvents used in the pretreatment of lignocellulosic biomass for further valorization were reviewed and summarised in Table 4.

\subsection{Other applications of ChCl-based solvents}

DESs/LTTMs find versatile applications in various fields and are not limited only to be used as solvents. DESs/LTTMs can be used as cheaper and environmentally benign alternatives to substitute for the use of conventional solvents in extraction, purification, or other separation processes. The applications of DESs/LTTMs were also reported in fields of chemical and polymer synthesis, metal electrodeposition, nanomaterials, $\mathrm{CO}_{2}$ capturing, biomass and biofuels processing, biomedicine, pharmaceutics, food processing, cosmetics, etc. (Ezgi Ünlü \& Takaç, 2020; Marcus, 2019; Paiva et al., 2014; Silva et al., 2019). Some other applications of $\mathrm{ChCl}$-based solvents include:

i. Microalgal biomass pre-treatment for the extraction of cellular

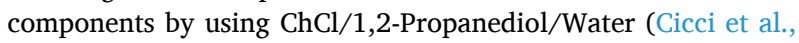
2017).

ii. Pretreatment and fractionation of keratinous waste biomass by using ChCl/Oxalic acid (Wang et al., 2018; Wang \& Tang, 2018), separation of aliphatic-aromatic mixtures by using $\mathrm{ChCl} /$ Malonic acid (Samarov et al., 2018).

iii. Extraction of phenolic compounds from wood-apple pulp by using ChCl/Oxalic acid (Saha et al., 2019).

iv. Extraction of polyphenols from palm samples by using $\mathrm{ChCl}$ / Formic acid, $\mathrm{ChCl} / \mathrm{Glycerol}, \mathrm{ChCl} /$ Acrylic acid, $\mathrm{ChCl} /$ Ethylene glycol, $\mathrm{ChCl} / \mathrm{Malonic}$ acid, $\mathrm{ChCl} / \mathrm{Citric}$ acid, $\mathrm{ChCl} / \mathrm{Xylitol}, \mathrm{ChCl} /$ Phenol, ChCl/Urea, and ChCl/Oxalic acid (Liu et al., 2019b).

v. Hydrogen sulfide $\left(\mathrm{H}_{2} \mathrm{~S}\right)$ absorption by using $\mathrm{ChCl} /$ Formic acid, $\mathrm{ChCl}$, Acetic acid, and $\mathrm{ChCl} /$ Propionic acid (Wu et al., 2019). 
Table 4

Applications of ChCl-based solvents in lignocellulosic biomass pretreatment.

\begin{tabular}{|c|c|c|c|}
\hline DESs/LTTMs & Application & Key Findings & Reference \\
\hline $\mathrm{ChCl} /$ Urea $1: 2$ & $\begin{array}{l}\text { Pretreatment of rice } \\
\text { straw biomass for the } \\
\text { isolation of } \\
\text { holocellulose, } \\
\alpha \text {-cellulose, and acid- } \\
\text { insoluble lignin (AIL) }\end{array}$ & $\begin{array}{l}\text { Attained highest } \\
\text { dissolution capacity } \\
\text { for AIL at } 22.87 \% \text {, } \\
\text { followed by } 16.71 \% \text { of } \\
\text { hemicellulose and } \\
\text { amorphous cellulose, } \\
\text { and } 9.60 \% \text { of } \\
\alpha \text {-cellulose. ChCl/Urea } \\
\text { also demonstrated } \\
\text { higher dissolution } \\
\text { selectivity on lignin. }\end{array}$ & $\begin{array}{l}\text { (Pan et al., } \\
\text { 2017) }\end{array}$ \\
\hline $\begin{array}{l}\mathrm{ChCl} / \text { Oxalic } \\
\text { acid } \\
\text { dihydrate } \\
1: 1\end{array}$ & $\begin{array}{l}\text { Pretreatment and } \\
\text { delignification of Poplar } \\
\text { wood lignocellulosic } \\
\text { biomass to extract } \\
\text { lignin oligomers }\end{array}$ & $\begin{array}{l}\text { The LTTMs coupled } \\
\text { with Microwave- } \\
\text { Assisted Extraction } \\
\text { (MAE), successfully } \\
\text { extracted lignin } \\
\text { oligomers of high } \\
\text { purity (about } 96 \% \text { ) } \\
\text { from the sample. }\end{array}$ & $\begin{array}{l}\text { (Liu et al., } \\
\text { 2017) }\end{array}$ \\
\hline $\begin{array}{l}\mathrm{ChCl} / \mathrm{L}-\text { Malic } \\
\text { acid/Water } \\
2: 4: 2 ; \\
\text { ChCl/Malic } \\
\text { acid } \\
\text { (cactus)/ } \\
\text { Water } 2: 4: 2\end{array}$ & $\begin{array}{l}\text { Delignification of oil } \\
\text { palm biomass residues }\end{array}$ & $\begin{array}{l}\text { Cactus malic acid can } \\
\text { attain a considerable } \\
\text { performance in lignin } \\
\text { removal compared to } \\
\text { L-malic acid, with } \\
\text { lignin removal at } \\
41.94 \% \text { by using ChCl/ } \\
\text { L-Malic acid/Water } \\
\text { while its cactus malic } \\
\text { acid variant attained } \\
37.22 \% \\
\text { delignification. }\end{array}$ & $\begin{array}{l}\text { (Yiin et al., } \\
\text { 2017) }\end{array}$ \\
\hline $\begin{array}{l}\mathrm{ChCl} / \text { Lactic } \\
\text { acid 1:9 }\end{array}$ & $\begin{array}{l}\text { Delignification of } \\
\text { tortoise-shell bamboo } \\
\text { (Phyllostachys } \\
\text { pubescens) for the } \\
\text { recovery of cellulose } \\
\text { nanofibers }\end{array}$ & $\begin{array}{l}\text { Most of the lignin was } \\
\text { efficiently removed } \\
\text { (up to } 94.39 \% \text { ) after } \\
\text { pre-treatment with } \\
\mathrm{ChCl} / \text { Lactic acid at } \\
120^{\circ} \mathrm{C} \text { over a duration } \\
\text { of } 3 \mathrm{~h} \text { with a solid-to- } \\
\text { solvent ratio of } 0.04 \\
\text { (w/w), and } 91 \% \\
\text { recovery of cellulose } \\
\text { was recorded. }\end{array}$ & $\begin{array}{l}\text { (Liu et al., } \\
\text { 2019a) }\end{array}$ \\
\hline $\begin{array}{l}\mathrm{ChCl} / \text { Lactic } \\
\text { acid 1:10 to } \\
1: 250\end{array}$ & $\begin{array}{l}\text { Delignification of Gum } \\
\text { tree (Eucalyptus } \\
\text { globulus) chips biomass } \\
\text { with small amount of } \\
\text { HBA }\end{array}$ & $\begin{array}{l}\mathrm{ChCl} / \mathrm{Lactic} \text { acid was } \\
\text { found to have a } \\
\text { slightly lower lignin } \\
\text { solubility compared to } \\
\text { pure lactic acid, } \\
\text { however, a surge in the } \\
\text { bond fission rate of } \\
\beta \text {-O-4 linkages of the } \\
\text { lignin was observed. }\end{array}$ & $\begin{array}{l}\text { (Smink } \\
\text { et al., } \\
\text { 2019) }\end{array}$ \\
\hline $\begin{array}{l}\mathrm{ChCl} / \text { Formic } \\
\text { acid } 1: 2\end{array}$ & $\begin{array}{l}\text { Pretreatment of lignin } \\
\text { to produce lignin with } \\
\text { tailor-made properties }\end{array}$ & $\begin{array}{l}\text { The regenerated lignin } \\
\text { samples were reported } \\
\text { to be } 44-75 \% \text { implying } \\
\text { that delignification } \\
\text { occurred to a certain } \\
\text { extent. }\end{array}$ & $\begin{array}{l}\text { (Hong } \\
\text { et al., } \\
2020 \text { ) }\end{array}$ \\
\hline $\begin{array}{l}\mathrm{ChCl} / \text { Lactic } \\
\text { acid; } \\
\text { ChCl/Oxalic } \\
\text { acid; } \\
\text { ChCl/Malic } \\
\text { acid; } \\
\text { ChCl/Urea; }\end{array}$ & $\begin{array}{l}\text { Pretreatment and } \\
\text { delignification of } \\
\text { Asplund pulp from } \\
\text { Norway spruce (Picea } \\
\text { abies) }\end{array}$ & $\begin{array}{l}\text { Around } 50 \% \text { lignin } \\
\text { removal was equally } \\
\text { achieved by using } \\
\mathrm{ChCl} / \text { Lactic acid, } \\
\mathrm{ChCl} \text { /Oxalic acid and } \\
\mathrm{ChCl} / \text { Urea DESs while } \\
\mathrm{ChCl} \text { /Malic acid } \\
\text { achieved significantly } \\
\text { less effective } \\
\text { delignification. }\end{array}$ & $\begin{array}{l}\text { (Fiskari } \\
\text { et al., } \\
\text { 2020) }\end{array}$ \\
\hline $\begin{array}{l}\text { ChCl/Acetic } \\
\text { acid 1:2; } \\
\text { ChCl/Formic } \\
\text { acid 1:2; } \\
\text { ChCl/Glycerol } \\
\text { 1:2; }\end{array}$ & $\begin{array}{l}\text { Pretreatment and } \\
\text { delignification of } \\
\text { miscanthus and } \\
\text { birchwood for lignin } \\
\text { extraction }\end{array}$ & $\begin{array}{l}\mathrm{ChCl} \text { /Oxalic acid } \\
\text { demonstrated the } \\
\text { highest delignification } \\
\text { efficiency for both the } \\
\text { miscanthus and } \\
\text { birchwood samples. } \\
\text { ChCl/Glycerol DES }\end{array}$ & $\begin{array}{l}\text { (Kohli } \\
\text { et al., } \\
2020 \text { ) }\end{array}$ \\
\hline
\end{tabular}

Table 4 (continued)

\begin{tabular}{|c|c|c|c|}
\hline DESs/LTTMs & Application & Key Findings & Reference \\
\hline $\begin{array}{c}\mathrm{ChCl} / \text { Lactic } \\
\text { acid 1:2; } \\
\mathrm{ChCl} / \text { Malic } \\
\text { acid } 1: 1 ; \\
\mathrm{ChCl} / \text { Oxalic } \\
\text { acid } 1: 1\end{array}$ & & $\begin{array}{l}\text { was reported to } \\
\text { produce the lowest } \\
\text { amount of recovered } \\
\text { lignin. }\end{array}$ & \\
\hline $\begin{array}{l}\mathrm{ChCl} / \text { Oxalic } \\
\text { acid 1:2; } \\
\text { ChCl/Urea 1:2 }\end{array}$ & $\begin{array}{l}\text { Pre-treatment and } \\
\text { delignification of } \\
\text { lignocellulosic bamboo } \\
\text { (Bambusa bambos) stem }\end{array}$ & $\begin{array}{l}\text { The delignification } \\
\text { using ChCl/Oxalic acid } \\
\text { exhibited a higher } \\
\text { lignin dissolution in } \\
\text { Bambusa bambos stem } \\
\text { with } 25.4 \% \text { maximum } \\
\text { lignin dissolution as } \\
\text { opposed to ChCl/Urea } \\
\text { that attained } 19.4 \% \\
\text { lignin dissolution at } \\
120^{\circ} \mathrm{C} \text { for } 10 \mathrm{~h} \text {. }\end{array}$ & $\begin{array}{l}\text { (Ramesh } \\
\text { et al., } \\
\text { 2020) }\end{array}$ \\
\hline $\begin{array}{l}\text { ChCl/Urea } \\
2: 1 ; \\
\text { ChCl/Citric } \\
\text { acid 2:1; } \\
\text { ChCl/Oxalic } \\
\text { acid } 2: 1 ; \\
\text { ChCl/Glycerol } \\
\text { 2:1; }\end{array}$ & $\begin{array}{l}\text { Dissolution of } \\
\text { microcrystalline } \\
\text { cellulose }\end{array}$ & $\begin{array}{l}\text { The highest dissolution } \\
\text { effect was } \\
\text { demonstrated by } \\
\mathrm{ChCl} / \text { Oxalic acid } 2: 1 \text {, } \\
\text { followed by } \mathrm{ChCl} / \\
\text { Citric acid } 2: 1, \mathrm{ChCl} / \\
\text { Urea } 2: 1 \text {, and } \mathrm{ChCl} / \\
\text { Glycerol } 2: 1 \text {, in } \\
\text { descending order of } \\
\text { cellulose solubility. }\end{array}$ & $\begin{array}{l}\text { (Zhang } \\
\text { et al., } \\
2020 \text { ) }\end{array}$ \\
\hline $\begin{array}{l}\text { ChChl/ } \\
\text { Ethylene } \\
\text { glycol 1:2 } \\
\text { ChCl/Glycerol } \\
\text { 1:2; } \\
\text { ChCl/Lactic } \\
\text { acid 1:2; } \\
\text { ChCl/Oxalic } \\
\text { acid 1:1; } \\
\text { ChCl/Urea 1:2 }\end{array}$ & $\begin{array}{l}\text { Pre-treatment for the } \\
\text { separation of lignin and } \\
\text { hemicellulose in dried } \\
\text { bagasse biomass } \\
\text { samples }\end{array}$ & $\begin{array}{l}\text { The solubility of lignin } \\
\text { in ChCl/Oxalic acid } \\
\text { was the highest } \\
\text { ( } 47.85 \% \text { ) but the } \\
\text { bagasse was } \\
\text { carbonized after } \\
\text { pretreatment. ChCl/ } \\
\text { Lactic acid was more } \\
\text { suitable for cellulose } \\
\text { separation while } \mathrm{ChCl/} \\
\text { Ethylene glycol, } \mathrm{ChCl/} \\
\text { Glycerol and } \mathrm{ChCl/} \\
\text { Urea had selectivity } \\
\text { towards lignin } \\
\text { separation. }\end{array}$ & $\begin{array}{l}\text { (Li et al., } \\
\text { 2021) }\end{array}$ \\
\hline $\begin{array}{l}\mathrm{ChCl} / \\
\text { Glycerol/ } \\
\mathrm{FeCl}_{3} \cdot 6 \mathrm{H}_{2} \mathrm{O} \\
62: 124: 1\end{array}$ & $\begin{array}{l}\text { Pre-treatment and } \\
\text { delignification of corn } \\
\text { stover biomass }\end{array}$ & $\begin{array}{l}\text { Delignification up to } \\
48.35 \% \text { and xylan } \\
\text { removal of } 59.15 \% \\
\text { from corn stover } \\
\text { samples by using lewis } \\
\text { acid catalyzed ChCl/ } \\
\text { Glycerol DES which } \\
\text { was lower than direct } \\
\text { pretreatment by using } \\
\text { individual ChCl and } \\
\text { glycerol solutions. } \\
\text { However, the } \\
\text { recyclability of ChCl/ } \\
\text { Glycerol DES was } \\
\text { significantly higher } \\
\text { than both ChCl and } \\
\text { glycerol aqueous } \\
\text { solution pretreatment. }\end{array}$ & $\begin{array}{l}\text { (Zhu et al., } \\
\text { 2021) }\end{array}$ \\
\hline
\end{tabular}

vi. Solvent extraction of phenolic constituents from olive leaves by using $\mathrm{ChCl} / \mathrm{Lactic}$ acid, $\mathrm{ChCl} / \mathrm{Oxalic}$ acid, $\mathrm{ChCl} /$ Tartaric acid, $\mathrm{ChCl} / 1$,4-Butylene glycol, $\mathrm{ChCl} /$ Ethylene glycol, $\mathrm{ChCl} /$ Xylitol, $\mathrm{ChCl} / 1,2-P r o p y l e n e$ glycol, $\mathrm{ChCl} /$ Maltose, and $\mathrm{ChCl} / \mathrm{Urea}$ (Alañón et al., 2020).

vii. $\mathrm{CO}_{2}$ capturing by using $\mathrm{ChCl} /$ Ethylene glycol, and $\mathrm{ChCl} / \mathrm{Glycerol}$ as solvents in absorption column (Alkhatib et al., 2020).

viii. $\mathrm{NH}_{3}$ absorption and separation by using DES formed from $\mathrm{ChCl}$ and dihydric alcohols (1,4-butanediol,2,3-butanediol, and 1,3propanediol) (Deng et al., 2020).

ix. Extraction of crude oil from contaminated soil (Duan et al., 2020). 
x. Pretreatment and extraction of polyphenols from chestnut shell waste $\mathrm{ChCl} /$ Ethylene glycol, $\mathrm{ChCl} / 1,4-\mathrm{Butanediol,} \mathrm{ChCl} / \mathrm{Oxalic}$ acid dihydrate, $\mathrm{ChCl} / \mathrm{Malic}$ acid, $\mathrm{ChCl} / \mathrm{Citric}$ acid hydrate, $\mathrm{ChCl} /$ Maltose 1:1, ChCl/Glucose 1:2 (Husanu et al., 2020).

xi. Extraction of oat protein by using $\mathrm{ChCl} / 1,2$-Butylene glycol,

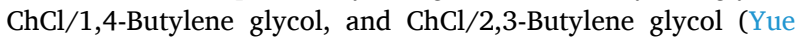
et al., 2020), and etc.

Considering the large possibilities for applications of ChCl-based solvents across a wide array of fields especially in biomass pretreatment for further processing, $\mathrm{ChCl}$ demonstrates high potential as the representative constituent of green solvents. The reported studies on biomass pretreatment using ChCl-based solvents delivered promising results on the delignification efficiency in several lignocellulosic biomass samples. For instance, delignification of tortoise-shell bamboo (Phyllostachys pubescens) of up to $94.39 \%$ lignin removal were reported with $\mathrm{ChCl} /$ Lactic acid pretreatment (Liu et al., 2019a). In addition, most studies also reported lignin removal in the range of $40-50 \%$ depending on the type of biomass and green solvents used. $\mathrm{ChCl} / \mathrm{Oxalic}$ acid also demonstrated the highest delignification efficiency in several biomass samples but the applicability could be restricted due to its toxicity and caustic properties (Kohli et al., 2020). In this sense, $\mathrm{ChCl} /$ Lactic acid and $\mathrm{ChCl} / \mathrm{Malic}$ acid are more preferable although they have lower delignification efficiency compared to oxalic acid based green solvents. As discussed herein, choline chloride is indeed a potential starting material which requires further exploration to unleash its full potential in terms of understanding the way it interacts with HBDs in the formation of DESs/LTTMs.

\section{Challenges and future prospects}

Advances in lignocellulosic biomass pretreatment techniques are continuously developed and improvised to improve the yield of certain substrates in the lignocellulosic biomass. Considering the recent emphasis on green chemistry, there will be a large room for advancements in green solvents for the pretreatment of lignocellulosic biomass considering the near-infinite possible combinations of DESs/LTTMs with different pairs of HBA and HBA.

Although active researches were devoted to the application of DESs/ LTTMs, comprehensive studies and characterisation of the physicochemical properties of DESs/LTTMs are still scarce. A gap exists in fully understanding DESs/LTTMs, which can be attributed to the ambiguity in the building principles, incomprehensive knowledge on the mechanisms of formation, as well as the intermolecular interactions within the solvent. After all, the pivotal key to explore deeper into DESs/LTTMs lies upon its fundamental, where its physicochemical properties play a significant role in modulating the species reactivity and behaviour of the DESs/LTTMs (Savi et al., 2019).

The future advances in this field could outseen the possibilities of developing green solvents with extraordinary performances in lignocellulosic biomass pretreatment through in-depth studies on the physicochemical properties of DESs/LTTMs with advanced design methodologies in formulating a task-specific DESs/LTTMs. Apart from that, the application and recycling of solvents are limited by their thermal instability and susceptibility to contaminants, which could interfere with interactions between HBAs and HBDs (Tang et al., 2017). Hence, on-going studies into the development of stable and recyclable DESs/LTTMs systems are needed.

Recent studies also underscored the concern associated with cytotoxic profiles of existing green solvents despite their low toxicity nature, especially for use in pharmaceuticals and therapeutic mediums which requires an essentially safe margin of toxic levels (Hayyan et al., 2016). Consequently, emerging trends of synthesis of solvents from natural sources to create natural deep eutectic solvents (NADES) (Mitar et al., 2019) and those certified safe for therapeutic means as in therapeutic deep eutectic solvents (THEDES) (Dwamena, 2019) could be outseen as the future prospects of green solvents.

\section{Conclusions}

Pretreatment process plays a significance role in disrupting the recalcitrant structure of lignocellulosic biomass to obtain the enzyme accessible substrates. DESs/LTTMs came up as the most promising alternative among other pretreatment technologies and solvents with their versatility and a highly tunable nature by just varying the composition of its constituents. The immense interest in $\mathrm{ChCl}$ sparked an exponential growth on the studies of ChCl-based solvents whereby most of them was applied in lignocellulosic biomass pretreatment. More detailed information on green solvents development associated with existing research gaps can contribute to the field of biomass-to-energy conversion in the future.

\section{CRediT authorship contribution statement}

Chung Loong Yiin: Conceptualization, Writing - original draft, Writing - review \& editing, Visualization, Supervision, Funding acquisition. Kok Liang Yap: Writing - original draft, Writing - review \& editing. Andrian Zi En Ku: Writing - original draft, Writing - review \& editing. Bridgid Lai Fui Chin: Writing - review \& editing. Serene Sow Mun Lock: Writing - review \& editing. Kin Wai Cheah: Writing - review \& editing. Adrian Chun Minh Loy: Writing - review \& editing. Yi Herng Chan: Writing - review \& editing.

\section{Declaration of Competing Interest}

The authors declare that they have no known competing financial interests or personal relationships that could have appeared to influence the work reported in this paper.

\section{Acknowledgements}

The authors would like to acknowledge the supports from Fundamental Research Grant Scheme Malaysia [F02/FRGS/2011/2020] and Small Grant Scheme UNIMAS [F02/SGS/1992/2020] with finance ID of 05-FA020700-0708-0051 and 05-FA020700-0613-0017, respectively.

\section{References}

Abbott, A.P., Capper, G., Davies, D.L., Rasheed, R.K., Tambyrajah, V., 2003. Novel solvent properties of choline chloride/urea mixtures. Chem. Commun. 1, 70-71.

Abood, H.M.A., Abbott, A.P., Ballantyne, A.D., Ryder, K.S., 2011. Do all ionic liquids need organic cations? Characterisation of $[\mathrm{AlCl} 2 \cdot \mathrm{nAmide}]+\mathrm{AlCl} 4-$ and comparison with imidazolium based systems. Chem. Commun. 47 (12), 3523-3525.

Abranches, D.O., Martins, M.A.R., Silva, L.P., Schaeffer, N., Pinho, S.P., Coutinho, J.A.P., 2019. Phenolic hydrogen bond donors in the formation of non-ionic deep eutectic solvents: the quest for type $\mathrm{V}$ des. Chem. Commun. 55 (69), 10253-10256.

Aguilar-Reynosa, A., Romaní, A., Ma. Rodríguez-Jasso, R., Aguilar, C.N., Garrote, G., Ruiz, H.A., 2017. Microwave heating processing as alternative of pretreatment in second-generation biorefinery: An overview. Energy Convers. Manage. 136, 50-65.

Alañón, M.E., Ivanović, M., Gómez-Caravaca, A.M., Arráez-Román, D., SeguraCarretero, A., 2020. Choline chloride derivative-based deep eutectic liquids as novel green alternative solvents for extraction of phenolic compounds from olive leaf. Arabian J. Chem. 13 (1), 1685-1701.

Alhadid, A., Mokrushina, L., Minceva, M., 2020. Design of deep eutectic systems: a simple approach for preselecting eutectic mixture constituents. Molecules 25 (5), 1077.

Alkhatib, I.I.I., Ferreira, M.L., Alba, C.G., Bahamon, D., Llovell, F., Pereiro, A.B., Araújo, J.M.M., Abu-Zahra, M.R.M., Vega, L.F., 2020. Screening of ionic liquids and deep eutectic solvents for physical CO2Absorption by Soft-SAFT using key performance indicators. J. Chem. Eng. Data 65 (12), 5844-5861.

Agu, O.S.G., Tabil, L., Meda, V., Dumonceaux, Edmund Mupondwav, T., 2019. Pretreatment of crop residues by application of microwave heating and alkaline solution for biofuel processing: a review. In: Renewable Resources and Biorefineries. IntechOpen.

Amin, F.R., Khalid, H., Zhang, H., Rahman, S.u., Zhang, R., Liu, G., Chen, C., 2017. Pretreatment methods of lignocellulosic biomass for anaerobic digestion. AMB Expr. 7 (1), 72. 
An, S., Li, W., Xue, F., Li, X., Xia, Y., Liu, Q., Chen, L., Jameel, H., Chang, H.M., 2020. Effect of removing hemicellulose and lignin synchronously under mild conditions on enzymatic hydrolysis of corn stover. Fuel Process. Technol. 204, 106407.

Anwar, Z., Gulfraz, M., Irshad, M., 2014. Agro-industrial lignocellulosic biomass a key to unlock the future bio-energy: a brief review. J. Radiat. Res. Appl. Sci. 7 (2), 163-173.

Azmin, S.N.H.M., Yunus, N.A., Mustaffa, A.A., Alwi, S.R.W., Chua, L.S., 2015. Computeraided approach for designing solvents blend for herbal phytochemical extraction. Comput. Aided Chem. Eng. 37, 1427-1432. Elsevier B.V.

Baaqel, H., Díaz, I., Tulus, Víctor, Chachuat, B., Guillén-Gosálbez, G., Hallett, J.P., 2020 Role of life-cycle externalities in the valuation of protic ionic liquids - a case study in biomass pretreatment solvents. Green Chem. 22 (10), 3132-3140.

Bai, X., Wang, G., Yu, Y., Wang, D., Wang, Z., 2018. Changes in the physicochemical structure and pyrolysis characteristics of wheat straw after rod-milling pretreatment. Bioresour. Technol. 250, 770-776.

Baruah, J., Nath, B.K., Sharma, R., Kumar, S., Deka, R.C., Baruah, D.C., Kalita, E., 2018. Recent trends in the pretreatment of lignocellulosic biomass for value-added products. Front. Energy Res. 6, 141.

Behera, S., Arora, R., Nandhagopal, N., Kumar, S., 2014. Importance of chemical pretreatment for bioconversion of lignocellulosic biomass. Renew. Sustain. Energy Rev. 36, 91-106.

Bergez-Lacoste, M., Thiebaud-Roux, S., De Caro, P., Fabre, J.-F., Gerbaud, V., Mouloungui, Z., 2014. From chemical platform molecules to new biosolvents: design engineering as a substitution methodology. Biofuels Bioprod. Bioref 8 (3), 438-451.

Bernasconi, R., Panzeri, G., Accogli, A., Liberale, F., Nobili, L., Magagnin, L., 2017. Electrodeposition from deep eutectic solvents. In: Progress and Developments in Ionic Liquids. InTech Open, pp. 235-262.

Bharathiraja, B., Jayamuthunagai, J., Chakravarthy, M., Kumar, R.P., 2018. Bioprocessing of biofuels for green and clean environment. In: Sivasubramanian, V. (Ed.), Bioprocess Engineering for a Green Environment. CRC Press, pp. 237-249.

Bhatia, S.K., Kim, S.-H., Yoon, J.-J., Yang, Y.-H., 2017. Current status and strategies for second generation biofuel production using microbial systems. Energy Convers. Manage. 148, 1142-1156.

Bhutto, A.W., Qureshi, K., Harijan, K., Abro, R., Abbas, T., Bazmi, A.A., Karim, S., Yu, G., 2017. Insight into progress in pre-treatment of lignocellulosic biomass. Energy 122, 724-745.

Bolado-Rodríguez, S., Toquero, C., Martín-Juárez, J., Travaini, R., García-Encina, P.A., 2016. Effect of thermal, acid, alkaline and alkaline-peroxide pretreatments on the biochemical methane potential and kinetics of the anaerobic digestion of wheat straw and sugarcane bagasse. Bioresour. Technol. 201, 182-190.

Borand, M.N., Karaosmanoglu, F., 2018. Effects of organosolv pretreatment conditions for lignocellulosic biomass in biorefinery applications: A review. J. Renew. Sustain. Energy 10 (3), 033104.

Brodeur, G., Yau, E., Badal, K., Collier, J., Ramachandran, K.B., Ramakrishnan, S., 2011. Chemical and physicochemical pretreatment of lignocellulosic biomass: a review. Enzyme Res. 2011 (1), 1-17.

Capolupo, L., Faraco, V., 2016. Green methods of lignocellulose pretreatment for biorefinery development. Appl. Microbiol. Biotechnol. 100 (22), 9451-9467.

Chen, H.-Z., Liu, Z.-H., 2015. Steam explosion and its combinatorial pretreatment refining technology of plant biomass to bio-based products. Biotechnol. J. 10 (6), 866-885.

Chen, H., Liu, J., Chang, X., Chen, D., Xue, Y., Liu, P., Lin, H., Han, S., 2017. A review on the pretreatment of lignocellulose for high-value chemicals. Fuel Process. Technol. 160, 196-206.

Chen, Y., Yu, D., Chen, W., Fu, L., Mu, T., 2019. Water absorption by deep eutectic solvents. Phys. Chem. Chem. Phys. 21 (5), 2601-2610.

Cicci, A., Sed, G., Bravi, M., 2017. Potential of choline chloride - based Natural Deep eutectic solvents (NaDES) in the extraction of microalgal metabolites. Chem. Eng. Trans. 57, 61-66.

Dahadha, S., Amin, Z., Bazyar Lakeh, A.A., Elbeshbishy, E., 2017. Evaluation of different pretreatment processes of lignocellulosic biomass for enhanced biomethane production. Energy Fuels 31 (10), 10335-10347.

Das, S., Mondal, A., Balasubramanian, S., 2017. Recent advances in modeling green solvents. Curr. Opin. Green Sustain. Chem. 5, 37-43.

Deng, X., Duan, X., Gong, L., Deng, D., 2020. Ammonia solubility, density, and viscosity of choline chloride-dihydric alcohol deep eutectic solvents. J. Chem. Eng. Data 65 (10), 4845-4854.

Duan, M., Luo, M., Yang, Z., Xiong, Y., Shi, P., Fang, S., Qin, S., 2020. Application of choline-based deep eutectic solvent for the extraction of crude-oil contaminated soils. Environ. Technol. 1-6.

Duque, A., Manzanares, P., Ballesteros, M., 2017. Extrusion as a pretreatment for lignocellulosic biomass: fundamentals and applications. Renew. Energy 114, $1427-1441$.

Durand, E., Lecomte, J., Villeneuve, P., 2015. Are emerging deep eutectic solvents (DES) relevant for lipase-catalyzed lipophilizations? OCL 22 (4), D408.

Dwamena, A.K., 2019. Recent advances in hydrophobic deep eutectic solvents for extraction. Separations 6 (1), 9.

El-Naggar, N.E.A., Deraz, S., Khalil, A., 2014. Bioethanol production from lignocellulosic feedstocks based on enzymatic hydrolysis: current status and recent developments. Biotechnology 13 (1), 1-21.

Ezgi Ünlü, A., Takaç, S., 2020. Use of deep eutectic solvents in the treatment of agroindustrial lignocellulosic wastes for bioactive compounds. In: Agroecosystems - Very Complex Environmental Systems. IntechOpen.

Fiskari, J., Ferritsius, R., Osong, S.H., Persson, A., Höglund, T., Immerzeel, P., Norgren, M., 2020. Deep eutectic solvent delignification to low-energy mechanical pulp to produce papermaking fibers. BioResources 15 (3), 6023-6032.
Francisco, M., van den Bruinhorst, A., Kroon, M.C., 2012. New natural and renewable low transition temperature mixtures (LTTMs): screening as solvents for lignocellulosic biomass processing. Green Chem. 14 (8), 2153.

Francisco, M., vandenBruinhorst, A., Kroon, M.C., 2013. Low-Transition-Temperature Mixtures (LTTMs): a new generation of designer solvents. Angew. Chem. Int. Ed. 52 (11), 3074-3085.

Fu, S.-F., Wang, F., Yuan, X.-Z., Yang, Z.-M., Luo, S.-J., Wang, C.-S., Guo, R.-B., 2015. The thermophilic $\left(55^{\circ} \mathrm{C}\right)$ microaerobic pretreatment of corn straw for anaerobic digestion. Bioresour. Technol. 175, 203-208.

Fukaya, Y., Iizuka, Y., Sekikawa, K., Ohno, H., 2007. Bio ionic liquids: room temperature ionic liquids composed wholly of biomaterials. Green Chem. 9 (11), 1155.

Gao, W., Lei, Z., Tabil, L.G., Zhao, R., 2020. Biological pretreatment by solid-state fermentation of oat straw to enhance physical quality of pellets. J. Chem. 2020.

Haraźna, K., Walas, K., Urbańska, P., Witko, T., Snoch, W., Siemek, A., Jachimska, B., Krzan, M., Napruszewska, B.D., Witko, M., Bednarz, S., Guzik, M., 2019. Polyhydroxyalkanoate-derived hydrogen-bond donors for the synthesis of new deep eutectic solvents. Green Chem. 21 (11), 3116-3126.

Hayyan, M., Mbous, Y.P., Looi, C.Y., Wong, W.F., Hayyan, A., Salleh, Z., Mohd-Ali, O., 2016. Natural deep eutectic solvents: cytotoxic profile. SpringerPlus 5 (1), 913.

Hong, S., Shen, X.J., Pang, B., Xue, Z.M., Cao, X.F., Wen, J.L., 2020. In-depth interpretation of the structural changes of lignin and formation of diketones during acidic deep eutectic solvent pretreatment. Green Chem. 22, 1851-1858.

Husanu, E., Mero, A., Rivera, J.G., Mezzetta, A., Ruiz, J.C., D’Andrea, F., Pomelli, C.S., Guazzelli, L., 2020. Exploiting deep eutectic solvents and ionic liquids for the valorization of chestnut shell waste. ACS Sustain. Chem. Eng. 8 (50), 18386-18399.

Hussin, M.S.A., Varanusupakul, P., Shahabuddin, S., Yih Hui, B., Mohamad, S., 2020. Synthesis and characterization of green menthol-based low transition temperature mixture with tunable thermophysical properties as hydrophobic low viscosity solvent. J. Mol. Liq. 308, 113015.

Jędrzejczyk, M., Soszka, E., Czapnik, M., Ruppert, A.M., Grams, J., 2019. Physical and chemical pretreatment of lignocellulosic biomass. In: Basile, A., Dalena, F. (Eds.), Second and Third Generation of Feedstocks. Elsevier, pp. 143-196.

Kalhor, P., Ghandi, K., 2019. Deep eutectic solvents for pretreatment, extraction, and catalysis of biomass and food waste. Molecules 24 (22), 1-37.

Kalita, E., Nath, B.K., Deb, P., Agan, F., Islam, M.R., Saikia, K., 2015. High quality fluorescent cellulose nanofibers from endemic rice husk: isolation and characterization. Carbohydr. Polym. 122, 308-313.

Kim, J.S., Lee, Y.Y., Kim, T.H., 2016. A review on alkaline pretreatment technology for bioconversion of lignocellulosic biomass. Bioresour. Technol. 199, 42-48.

Kohli, K., Katuwal, S., Biswas, A., Sharma, B.K., 2020. Effective delignification of lignocellulosic biomass by microwave assisted deep eutectic solvents. Bioresour. Technol. 303, 122897.

Kottaras, P., Koulianos, M., Makris, D., 2017. Low-Transition Temperature Mixtures (LTTMs) made of bioorganic molecules: enhanced extraction of antioxidant phenolics from industrial cereal solid wastes. Recycling 2 (1), 3.

Kovács, A., Neyts, E.C., Cornet, I., Wijnants, M., Billen, P., 2020. Modeling the physicochemical properties of natural deep eutectic solvents. ChemSusChem 13, 3789-3804.

Kumar, A.K., Sharma, S., 2017. Recent updates on different methods of pretreatment of lignocellulosic feedstocks: a review. Bioresour. Bioprocess. 4 (1), 7.

Kumar, A., Anushree, Kumar, J., Bhaskar, T., 2020. Utilization of lignin: a sustainable and eco-friendly approach. J. Energy Inst. 93 (1), 235-271.

Li, C., Huang, C., Zhao, Y., Zheng, C., Su, H., Zhang, L., Huang, L.J., 2021. Effect of choline-based deep eutectic solvent pretreatment on the structure of cellulose and lignin in bagasse. Processes 9 (2), 384.

Li, H., Qu, Y., Yang, Y., Chang, S., Xu, J., 2016. Microwave irradiation - a green and efficient way to pretreat biomass. Bioresour. Technol. 199, 34-41.

Li, X., Sun, C., Zhou, B., He, Y., 2015. Determination of hemicellulose, cellulose and lignin in moso bamboo by near infrared spectroscopy. Sci. Rep. 5 (1), 17210.

Liu, Q., Yuan, T., Fu, Q.-jin., Bai, Y.-yuan., Peng, F., Yao, C.-li., 2019a. Choline chloridelactic acid deep eutectic solvent for delignification and nanocellulose production of moso bamboo. Cellulose 26 (18), 9447-9462.

Liu, Y., Chen, W., Xia, Q., Guo, B., Wang, Q., Liu, S., Liu, Y., Li, J., Yu, H., 2017. Efficient cleavage of lignin-carbohydrate complexes and ultrafast extraction of lignin oligomers from wood biomass by microwave-assisted treatment with deep eutectic solvent. ChemSusChem 10 (8), 1692-1700.

Liu, X., Fu, N., Zhang, Q., Cai, S., Wang, Q., Han, D., Tang, B., 2019b. Green tailoring with water of choline chloride deep eutectic solvents for the extraction of polyphenols from palm samples. J. Chromatogr. Sci. 57 (3), 272-278.

Liyakathali, N.A.M., Muley, P.D., Aita, G., Boldor, D., 2016. Effect of frequency and reaction time in focused ultrasonic pretreatment of energy cane bagasse for bioethanol production. Bioresour. Technol. 200, 262-271.

Louis, A.C.F., Venkatachalam, S., 2020. Energy efficient process for valorization of corn $\mathrm{cob}$ as a source for nanocrystalline cellulose and hemicellulose production. Int. J. Biol. Macromol. 163, 260-269.

Luo, J., Fang, Z., Smith, R.L., 2014. Ultrasound-enhanced conversion of biomass to biofuels. Prog. Energy Combust. Sci. 41, 56-93.

Mainberger, S., Kindlein, M., Bezold, F., Elts, E., Minceva, M., Briesen, H., 2017. Deep eutectic solvent formation: a structural view using molecular dynamics simulations with classical force fields. Mol. Phys. 115 (9-12), 1309-1321.

Mallakpour, S., Dinari, M., 2012. Ionic liquids as green solvents: progress and prospects. In: Green Solvents II: Properties and Applications of Ionic Liquids. Springer, Netherlands, pp. 1-32.

Mansor, A.M., Lim, J.S., Ani, F.N., Hashim, H., Ho, W.S., 2019. Characteristics of cellulose, hemicellulose and lignin of MD2 pineapple biomass. Chem. Eng. Trans. 72 , 79-84. 
Marcus, Y., 2019. Applications of deep eutectic solvents. In: Marcus, Y. (Ed.), Deep Eutectic Solvents. Springer International Publishing, Cham, pp. 111-151.

Maurya, D.P., Singla, A., Negi, S., 2015. An overview of key pretreatment processes for biological conversion of lignocellulosic biomass to bioethanol. 3 Biotech 5, 597-609.

Mitar, A., Panić, M., Kardum, J.P., Halambek, J., Sander, A., Kučan, K.Z., Redovniković, I.R., Radošević, K., 2019. Physicochemical properties, cytotoxicity, and antioxidative activity of natural deep eutectic solvents containing organic acid. Chem. Biochem. Eng. Q. 33 (1), 1-18.

Mood, S.H., Hossein Golfeshan, A., Tabatabaei, M., Salehi Jouzani, G., Najafi, G.H., Gholami, M., Ardjmand, M., 2013. Lignocellulosic biomass to bioethanol, a comprehensive review with a focus on pretreatment. Renew. Sustain. Energy Rev. 27, 77-93.

Nauman Aftab, M., Iqbal, I., Riaz, F., Karadag, A., Tabatabaei, M., 2019. Different pretreatment methods of lignocellulosic biomass for use in biofuel production. In: Biomass for Bioenergy - Recent Trends and Future Challenges. IntechOpen.

Noshadi, I., Walker, B.W., Portillo-Lara, R., Sani, E.S., Gomes, N., Aziziyan, M.R., Annabi, N., 2017. Engineering biodegradable and biocompatible bio-ionic liquid conjugated hydrogels with tunable conductivity and mechanical properties. Sci. Rep. 7 (1), 1-18.

Paiva, A., Craveiro, R., Aroso, I., Martins, M., Reis, R.L., Duarte, A.R.C., 2014. Natural deep eutectic solvents - solvents for the 21st century. ACS Sustain. Chem. Eng. 2 (5), 1063-1071.

Pan, M., Zhao, G., Ding, C., Wu, B., Lian, Z., Lian, H., 2017. Physicochemical transformation of rice straw after pretreatment with a deep eutectic solvent of choline chloride/urea. Carbohydr. Polym. 176, 307-314.

Peña-Lucio, E.M., Londoño-Hernández, L., Ascacio-Valdes, J.A., Chavéz-González, M.L. Bankole, O.E., Aguilar, C.N., 2020. Use of coffee pulp and sorghum mixtures in the production of n-demethylases by solid-state fermentation. Bioresour. Technol. 305, 123112.

Pielhop, T., Amgarten, J., von Rohr, P.R., Studer, M.H., 2016. Steam explosion pretreatment of softwood: the effect of the explosive decompression on enzymatic digestibility. Biotechnol. Biofuels 9 (1), 152.

Rajendran, K., Drielak, E., Sudarshan Varma, V., Muthusamy, S., Kumar, G., 2018. Updates on the pretreatment of lignocellulosic feedstocks for bioenergy production-a review. Biomass Conv. Bioref. 8 (2), 471-483.

Ramesh, R., Nair, A., Jayavel, A., Sathiasivan, K., Rajesh, M., Ramaswamy, S., Tamilarasan, K., 2020. Choline chloride-based deep eutectic solvents for efficient delignification of Bambusa bambos in bio-refinery applications. Chem. Pap. 74 (12), 4533-4545.

Ratnasingam, J., Ramasamy, G., Tau Wai, L., Senin, A.L., Muttiah, N., 2015. The prospects of rubberwood biomass energy production in Malaysia. BioResources 10 (2), 2526-2548.

Ratti, R., 2014. Ionic liquids: synthesis and applications in catalysis. Adv. Chem. 2014, $1-16$.

Ravindran, R., Jaiswal, A.K., 2016. A comprehensive review on pre-treatment strategy for lignocellulosic food industry waste: Challenges and opportunities. Bioresour. Technol. 199, 92-102.

Reddy, K.O., Maheswari, C.U., Dhlamini, M.S., Mothudi, B.M., Kommula, V.P., Zhang, J., Zhang, J., Rajulu, A.V., 2018. Extraction and characterization of cellulose single fibers from native African napier grass. Carbohydr. Polym. 188, 85-91.

Reis, R.S., Tienne, L.G.P., Souza, D.de.H.S., Marques, M.de.F.V., Monteiro, S.N., 2020. Characterization of coffee parchment and innovative steam explosion treatment to obtain microfibrillated cellulose as potential composite reinforcement. J. Mater. Res. Technol. 9 (4), 9412-9421.

Rodriguez-Donis, I., Thiebaud-Roux, S., Lavoine, S., Gerbaud, V., 2018. Computer-aided product design of alternative solvents based on phase equilibrium synergism in mixtures. C. R. Chim. 21 (6), 606-621.

Saha, S.K., Dey, S., Chakraborty, R., 2019. Effect of choline chloride-oxalic acid based deep eutectic solvent on the ultrasonic assisted extraction of polyphenols from Aegle marmelos. J. Mol. Liq. 287, 110956.

Samarov, A.A., Smirnov, M.A., Sokolova, M.P., Toikka, A.M., 2018. Liquid-liquid equilibrium data for the system N-Octane + Toluene + DES at 293.15 and $313.15 \mathrm{~K}$ and atmospheric pressure. Theor. Found. Chem. Eng. 52 (2), 258-263.

Santos, J., Ouadi, M., Jahangiri, H., Hornung, A., 2020. Valorisation of lignocellulosic biomass investigating different pyrolysis temperatures. J. Energy Inst. 93 (5), 1960-1969.

Savi, L.K., Dias, M.C.G.C., Carpine, D., Waszczynskyj, N., Ribani, R.H., Haminiuk, C.W.I., 2019. Natural deep eutectic solvents (NADES) based on citric acid and sucrose as a potential green technology: a comprehensive study of water inclusion and its effect on thermal, physical and rheological properties. Int. J. Food Sci. Technol. 54 (3), 898-907.

Scholl, A.L., Menegol, D., Pitarelo, A.P., Fontana, R.C., Filho, A.Z., Ramos, L.P., Dillon, A. J.P., Camassola, M., 2015. Elephant grass pretreated by steam explosion for inducing secretion of cellulases and xylanases by Penicillium echinulatum S1M29 solid-state cultivation. Ind. Crops Prod. 77, 97-107.

Shirkavand, E., Baroutian, S., Gapes, D.J., Young, B.R., 2016. Combination of fungal and physicochemical processes for lignocellulosic biomass pretreatment - a review. Renew. Sustain. Energy Rev. 54, 217-234.

Silva, J.M., Pereira, C.V., Mano, F., Silva, E., Castro, V.I.B., Sá-Nogueira, I., Reis, R.L., Paiva, A., Matias, A.A., Duarte, A.R.C., 2019. Therapeutic role of deep eutectic solvents based on menthol and saturated fatty acids on wound healing. ACS Appl. Bio Materials 2 (10), 4346-4355.

Sindhu, R., Binod, P., Pandey, A., 2016. Biological pretreatment of lignocellulosic biomass - an overview. Bioresour. Technol. 199, 76-82.
Singh, J., Suhag, M., Dhaka, A., 2015. Augmented digestion of lignocellulose by steam explosion, acid and alkaline pretreatment methods: a review. Carbohydr. Polym. $117,624-631$.

Smink, D., Juan, A., Schuur, B., Kersten, S.R.A., 2019. Understanding the role of choline chloride in deep eutectic solvents used for biomass delignification. Ind. Eng. Chem. Res. 58 (36), 16348-16357.

Smith, E.L., Abbott, A.P., Ryder, K.S., 2014. Deep Eutectic Solvents (DESs) and their applications. Chem. Rev. 114 (21), 11060-11082.

Sun, S., Sun, S., Cao, X., Sun, R., 2016. The role of pretreatment in improving the enzymatic hydrolysis of lignocellulosic materials. Bioresour. Technol. 199, 49-58.

Tang, X., Zuo, M., Li, Z., Liu, H., Xiong, C., Zeng, X., Sun, Y., Hu, L., Liu, S., Lei, T., Lin, L., 2017. Green processing of lignocellulosic biomass and its derivatives in deep eutectic solvents. ChemSusChem 10 (13), 2696-2706.

Taylor, M., Alabdrabalameer, H., Skoulou, V., 2019. Choosing physical, physicochemical and chemical methods of pre-treating lignocellulosic wastes to repurpose into solid fuels. Sustainability 11 (13), 3604.

Verardi, A., Blasi, A., Marino, T., Molino, A., Calabrò, V., 2018. Effect of steampretreatment combined with hydrogen peroxide on lignocellulosic agricultural wastes for bioethanol production: analysis of derived sugars and other by-products. J. Energy Chem. 27 (2), 535-543.

Wagner, A., Lackner, N., Mutschlechner, M., Prem, E., Markt, R., Illmer, P., 2018. Biological pretreatment strategies for second-generation lignocellulosic resources to enhance biogas production. Energies 11 (7), 1797.

Wang, D., Tang, R.-C., 2018. Dissolution of wool in the choline chloride/oxalic acid deep eutectic solvent. Mater. Lett. 231, 217-220.

Wang, D., Yang, X.H., Tang, R.C., Yao, F., 2018. Extraction of keratin from rabbit hair by a deep eutectic solvent and its characterization. Polymers 10 (9).

Welton, T., 2015. Solvents and sustainable chemistry. Proc. Royal Soc. A: Math. Phys. Eng. Sci. 471 (2183).

Wu, H., Shen, M., Chen, X., Yu, G., Abdeltawab, A.A., Yakout, S.M., 2019. New absorbents for hydrogen sulfide: deep eutectic solvents of tetrabutylammonium bromide/carboxylic acids and choline chloride/carboxylic acids. Sep. Purif. Technol. 224, 281-289.

Xu, G.-C., Ding, J.-C., Han, R.-Z., Dong, J.-J., Ni, Y., 2016. Enhancing cellulose accessibility of corn stover by deep eutectic solvent pretreatment for butanol fermentation. Bioresour. Technol. 203, 364-369.

Yiin, C.L., Ho, S., Yusup, S., Quitain, A.T., Chan, Y.H., Loy, A.C.M., Gwee, Y.L., 2019. Recovery of cellulose fibers from oil palm empty fruit bunch for pulp and paper using green delignification approach. Bioresour. Technol. 290, 121797.

Yiin, C.L., Quitain, A.T., Yusup, S., Uemura, Y., Sasaki, M., Kida, T., 2017. Choline chloride $(\mathrm{ChCl})$ and monosodium glutamate (MSG)-based green solvents from optimized cactus malic acid for biomass delignification. Bioresour. Technol. 244, 941-948.

Yiin, C.L., Quitain, A.T., Yusup, S., Uemura, Y., Sasaki, M., Kida, T., 2018. Sustainable green pretreatment approach to biomass-to-energy conversion using natural hydrolow-transition-temperature mixtures. Bioresour. Technol. 261, 361-369.

Yoo, C.G., Pu, Y., Ragauskas, A.J., 2017. Ionic liquids: promising green solvents for lignocellulosic biomass utilization. Curr. Opin. Green Sustain. Chem. 5, 5-11.

Yue, J., Zhu, Z., Yi, J., Lan, Y., Chen, B., Rao, J., 2020. Structure and functionality of oat protein extracted by choline chloride-dihydric alcohol deep eutectic solvent and its water binary mixtures. Food Hydrocolloids 112, 106330.

Zabed, H., Sahu, J.N., Boyce, A.N., Faruq, G., 2016. Fuel ethanol production from lignocellulosic biomass: An overview on feedstocks and technological approaches. Renew. Sustain. Energy Rev. 66, 751-774.

Zdanowicz, M., Wilpiszewska, K., Spychaj, T., 2018. Deep eutectic solvents for polysaccharides processing. A review. Carbohydr. Polym. 200, 361-380.

Zhang, K., Pei, Z., Wang, D., 2016. Organic solvent pretreatment of lignocellulosic biomass for biofuels and biochemicals: a review. Bioresour. Technol. 199, 21-33.

Zhang, Q., Tan, X., Wang, W., Yu, Q., Chen, X., Miao, C., Guo, Y., Zhang, Y., Zhuang, X., Sun, Y., Kong, X., Yuan, Z., 2020. A novel recyclable alkaline biphasic 2-phenoxyethanol/water system for rice straw biorefinery under mild conditions. ACS Sustain. Chem. Eng. 8 (20), 7649-7655.

Zhao, W., Yang, R., Zhang, Y., Wu, L., 2012. Sustainable and practical utilization of feather keratin by an innovative physicochemical pretreatment: high density steam flash-explosion. Green Chem. 14 (12), 3352.

Zhao, W., Chi, X., Li, H., He, J., Long, J., Xu, Y., Yang, S., 2019. Eco-friendly acetylcholine-carboxylate bio-ionic liquids for controllable: N-methylation and Nformylation using ambient CO2 at low temperatures. Green Chem. 21 (3), 567-577.

Zhekenov, T., Toksanbayev, N., Kazakbayeva, Z., Shah, D., Mjalli, F.S., 2017. Formation of type III Deep Eutectic Solvents and effect of water on their intermolecular interactions. Fluid Phase Equilib. 441, 43-48.

Zhou, T., McBride, K., Linke, S., Song, Z., Sundmacher, K., 2020. Computer-aided solvent selection and design for efficient chemical processes. Curr. Opin. Chem. Eng. 27, 35-44.

Zhu, Y., Qi, B., Liang, X., Luo, J., Wan, Y., 2021. Comparison of corn stover pretreatments with lewis acid catalyzed choline chloride, glycerol and choline chloride-glycerol deep eutectic solvent. Polymers 13 (7), 1170.

Zhuang, X., Wang, W., Yu, Q., Qi, W., Wang, Q., Tan, X., Zhou, G., Yuan, Z., 2016. Liquid hot water pretreatment of lignocellulosic biomass for bioethanol production accompanying with high valuable products. Bioresour. Technol. 199, 68-75.

Zoghlami, A., Paës, G., 2019. Lignocellulosic biomass: understanding recalcitrance and predicting hydrolysis. Front. Chem. 7, 874. 